\title{
Experimental Study on the Shear Performance of T-section Beams of Glued Timber
}

\author{
Junzhu Li, Jiejun Wang*and Quan Peng \\ ${ }^{1}$ School of Civil Engineering, Central South University of Forestry and Technology, Changsha 410004, China
}

Received 3 January 2021; Accepted 2 March 2021

\begin{abstract}
As a common engineering timber member used in the construction of timber bridges, a glulam T-beam has good mechanical properties. However, the low shear strength and various natural defects of timber cause the glulam T-beam to be prone to shear failure under load, and its shear performance is affected by web width and shear span ratio. To reveal the influences of web width and shear span ratio on the shear performance of glulam T-beams, five groups (10 in total) of glulam T-beam components and one group ( 2 in total) of glulam rectangular beam components were designed and manufactured with Larix gmelinii as a raw material. The deflection, strain, and ultimate bearing capacity of each component were measured using the mid-span concentrated force loading method. The failure mode of the component was observed, and its failure mechanism was discussed. The strain, deflection, and ultimate bearing capacity of each component were compared and analyzed. The calculation formula of the shear bearing capacity of a plywood T-beam was proposed. Results show that the failure mode of glued timber T-beam is shear failure along the grain. Compared with a rectangular beam, the ultimate bearing capacity of a glulam T-beam is increased by $71.36 \%$ on average, and the bending stiffness is increased by $131.28 \%$ on average. The shear capacity and bending rigidity of the glulam T-beam increase with the increase in web width and decrease with the increase in shear span ratio. The formula presented in this paper is reasonable and reliable, and the theoretical calculation value agrees well with the test value. This study can provide a reference for the engineering application and design of glulam T-beams.
\end{abstract}

Keywords: Glulam T-beam, Web width, Shear span ratio, Shear capacity, Shear failure along grain

\section{Introduction}

The greatest problem of reinforced concrete and steel structure buildings is that raw materials are not environmentally friendly and nonrenewable. The processing of raw materials will cause serious pollution and consume a large number of resources, which does not meet the current development theme of "green and environmental protection" and seriously restricts the sustainable development of the economy. Chinese timber structures have a long history, but traditional timber structures have high requirements for timber diameter, which will lead to a great waste of forest resources. Since the 1980s, the lack of forest resources in China has led to the stagnation of the development of timber structure buildings for more than 20 years. Since the $21 \mathrm{st}$ century, China has paid increasing attention to the development of timber structure buildings, and the scientific study and technical exchanges with foreign authorities in this field have been increasing. Wooden structures have entered a new stage of development. Compared with reinforced concrete and traditional timber members, glulam members have the following advantages:(1).The raw materials are renewable, and green environmental protection is promoted.(2).The size of members is less affected by the material diameter and can be processed in accordance with the demand.(3). The physical and mechanical properties are excellent.(4). The fire and corrosion resistance after treatment is exceptional.(5).The processing and installation are convenient. Glulam members are widely used in the construction of buildings and bridges [1-2].

However, buildings made of timber, as a natural material, have defects, such as knots and cracks, and anisotropic characteristics. This condition leads to the complex stress state of glulam beams in the stress process, and its mechanical properties are affected by many factors. It also causes great challenges to the study of glulam beams.

On this basis, scholars have performed numerous studies on the mechanical properties of glulam beams [3-18]. Nevertheless, most of the studies focus on the flexural and shear properties of rectangular glulam beams, and the study on the shear properties of glulam T-beams is much less. Studies on the relationship between the shear properties of glulam T-beams and web width and shear span ratio and the derivation of the calculation formula of the shear capacity of glulam T-beams are also rare. Therefore, exploring the shear performance of glulam T-beams, clarifying its relationship with web width and shear span ratio, and proposing the calculation formula of the shear capacity of glulam T-beams should be made urgently.

Accordingly, this study compares and analyzes the bearing capacity, deflection, and strain of all components through the shear test of glulam T-beams. The objectives are to explore the relationship between the shear performance of glulam T-beams and web width and shear span ratio, propose the calculation formula of the shear capacity of glulam T-beams, and provide a reference for engineering design. 


\section{State of the Art}

Scholars have conducted considerable exploration on the mechanical properties of glulam beams. For instance, F. J. Keenan et al. performed mid-span concentrated load mechanical tests on spruce glulam beams with different sizes and found that the shear strength of spruce glulam beams was inconsiderably correlated with component volume but was dependent on shear area. However, the test focused only on glulam beams made of spruce as webs, and whether the results were universal requires further study [3]. Soltis and Gerhardt summarized the results of shear stress and strength of glulam rectangular beams by many scholars. The findings showed that the shear strength of glulam rectangular beams depended on the beam size, but this relationship had not been fully verified. Further study should determine the influences of beam size, load configuration, cracks, and combined stress on shear strength. Existing theories should be validated in a wide range of variables [4]. To explore the relationship between the shear strength and the beam size, bending strength, and shear block strength of timber buildings, Rammer and Soltis tested the shear and bending strength of glulam beams with different sizes of southern pine and Douglas fir by using a five-point bending method and a concentrated force loading method. The results showed that the shear strength of glulam beams decreased with the increase in shear area and increased with the increase in shear block strength, and the shear strength was independent of bending strength. Nevertheless, whether the results apply to other glulam beams needs further study [5]. Lam and Craig used three test methods to study the shear strength of structural composite lumber (SCL) members. The results showed that the five-point bending test produced high shear strength and failure rate, but the effect of volume stress caused by the differences in test configuration and cross-section geometry on the shear strength of SCL was inadequately considered in the analysis [6]. Shanta Das conducted static load and fatigue tests of timber building beams with end cracks to determine their shear strength. However, no test was performed for beams without cracks. The limitation of the number of beams and test time caused the number of timber building beams used for the fatigue test to be very small, and the results did not necessarily reflect the true strength of timber building beams [7]. Kazeroon, Ahmedand, and Bkhari studied the effect of span on the bending properties of tropical hardwood glulam beams and found that bending modulus increased with the increase in span. Damage mainly occurred in the finger joint. Nonetheless, the results are inapplicable to large-sized and non-finger joint members [8]. KlapáLek and Melzerová established a finite element model to simulate a defective glulam beam, analyzed the influence of knots on the strength of glulam beams, and compared the results of finite element analysis with the results of the static test. However, only one glulam beam was studied in the test, and additional beams should be studied to verify the results [9]. To improve the mechanical properties and reliability of glulam beams, Ivan Glišović et al. [10] strengthened glulam beams with carbon fiber-reinforced plastic plates and compared the mechanical properties of strengthened and unreinforced beams. Nevertheless, the effects of different materials and geometric shapes on the strength and stiffness of glulam beams, longterm reliability in consideration of bond performance, and the performance of strengthened beams under cyclic and dynamic loads were not considered. João Gomes Ferreira et al. [11] studied the failure behavior and repair of delaminated glulam beams, the effect of different types of delamination of straight glulam beams on their structural behavior up to failure, the effectiveness of repairing these beams after bending failure with self-drilling screws, and the effectiveness of preventive repair of these beams with selfdrilling screws.

$\mathrm{Du} \mathrm{H}$ et al. [12] studied the shear performance of inclined screws in glulam-concrete composite beams through pushout tests and proposed a calculation method for the shear capacity of inclined screws in glulam-concrete composite beams, but they did not explore the influencing factors of the shear capacity of screw connectors. Zhang J et al. [13-14] studied the bending performance of internal prestressed glulam beams by using theoretical and experimental methods. A discriminant method for tensile and compressive failure modes was proposed. The formula of the ultimate bearing capacity of components was deduced. The influences of the linear type of prestressed tendons, bonding, and tension control stress on the bending performance of glulam beams were explored. Their study provided a reference for the design and application of prestressed glulam components. However, the influence of long-term load on components and the mechanical properties of components in the elastic-plastic stage were not considered. To understand the mechanical properties of glulam beams further and provide a basis for engineering design, Zhou S R et al. [15] studied the bending properties of clear wood specimens and full-scale glulam beams. Their study provided a basis for the design of glulam beams with a large size and a small span-depth ratio commonly used in engineering. Feng $\mathrm{J}$ et al. [16] performed a bending test of full-scale glued laminated beams with finger joint and analyzed the influences of beam height, finger-joint position, and other factors on the mechanical properties and failure mode of glulam beams. The results were greatly affected by the bonding quality of components. Rao Z Y et al. revealed the negative bending performance of glulam T-beams by combining theoretical analysis and finite element simulation, but the number of specimens was small and the section type was single [17]. Yang $T$ et al. carried out an experiment on the bending capacity of a T-beam in a glulam gallery bridge, revealed that the main form of bending failure of the glulam T-beam was shear failure along the grain, and proposed a theoretical calculation method for the bending capacity of glulam T-beams. Nonetheless, the shear lag effect was not considered in the test [18].

The abovementioned studies mainly focused on the flexural performance of glulam rectangular beams. Few studies exist on the shear performance of glulam beams, especially the shear performance of glulam T-beams and its influencing factors. In this study, six groups of 12 glulam beams were designed and manufactured. Mid-span concentrated load loading test was conducted, and the shear performance and failure mechanism were discussed. The influences of web width and shear span ratio on the shear performance were revealed, and the calculation formulas of the shear strength and bearing capacity of glulam T-beams were proposed. This study provides a basis for promoting the application and design of glulam T-beams in the field of timber bridges.

The remainder of this study is organized as follows. Section 3 introduces the material properties, design dimension, loading device, and measurement scheme of components. Section 4 describes the failure mode and mechanism of components, analyzes the load-deflection curve, load-strain curve, strain distribution curve along the 
width direction of the flange under different loads in detail, and introduces the calculation formulas of the shear strength and bearing capacity of glulam T-beams. Section 5 summarizes the entire study, provides the relevant conclusions and discusses the problems to be solved in the future.

\section{Methodology}

\subsection{Component materials and design}

Five groups (10 in total) of T-shaped beam members and one group ( 2 in total) of rectangular beam members were designed. The members were made of Larix gmelinii as raw material and cemented with a new type of water-based polyurethane structural adhesive to ensure that the cementation strength was higher than the shear and tensile strength of the timber. During the processing, the sawn timber was visually graded, and the sawn timber with straight grain and fewer defects were selected to make glulam components. The flange of the T-beam was cemented using sawn lumber with a thickness of $30 \mathrm{~mm}$ and widths of 145 and $105 \mathrm{~mm}$. The web was cemented using six sawn lumbers with a thickness of $30 \mathrm{~mm}$ and a width of $70 \mathrm{~mm}$ (or 60 or $80 \mathrm{~mm}$ ). The rectangular beam was cemented using six sawn lumbers with a thickness of $30 \mathrm{~mm}$ and a width of $70 \mathrm{~mm}$. During cementation, the sawn timber with the highest visual level was placed on the upper and lower surfaces of the glulam beam, and wood knots were not allowed in the mid-span area of the glulam beam to ensure that the components would not be damaged prematurely due to wood defects and thus lead to test failure. A $30 \mathrm{~mm}$-thick diaphragm was added to the support of each T-beam member to prevent local compression failure at the timber beam support. The moisture content of the wood was measured in accordance with "Method for determination of moisture content of wood [19]", and the average moisture content of this batch of wood was $13.67 \%$. The shear strength along the grain of the wood was determined in accordance with "Method of testing in shearing strength parallel to the grain of wood [20]", and the shear strength along the grain of this batch of wood was $7 \mathrm{MPa}$. The physical and mechanical properties of wood [21-22] are shown in Table 1, and the mechanical property parameters of structural adhesive are shown in Table 2.

Group A, B, and C members (test group 1) have the same shear span ratio and different web widths to explore the influence of section area on the shear strength of members. Group A, D, and E members (test group 2) have the same cross-sectional area and different shear span ratios to explore the influence of shear span ratio on the shear performance of glulam T-beams. Group $\mathrm{F}$ is a rectangular beam control group to explore the improvement of the mechanical properties of T-beam components. The component construction diagram is shown in Fig. 1, and the specific parameters of the components are shown in Table 3.

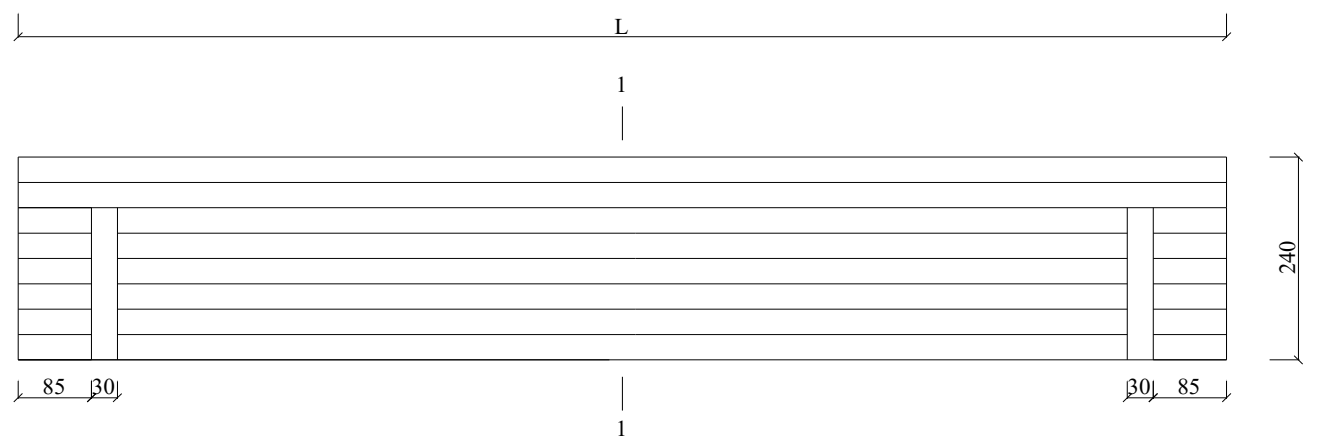

a) T-beam (mm)

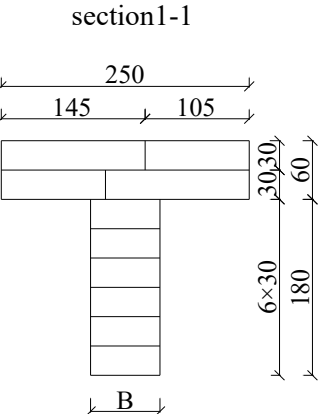

section2-2

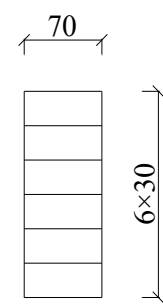

Fig. 1. Component construction drawing (mm)

b) Rectangular beam ( $\mathrm{mm})$

Table 1. Physical and mechanical properties of wood

\begin{tabular}{c|c|c|c|c|c|c|c}
\hline Material & $\begin{array}{c}\text { Initial } \\
\text { density } \\
/\left(\mathbf{g} \cdot \mathbf{c m}^{-\mathbf{3}}\right)\end{array}$ & $\begin{array}{c}\text { Water } \\
\text { content } \\
/ \%\end{array}$ & $\begin{array}{c}\text { Tensile strength } \\
\text { parallel to grain } \\
/ \mathbf{M P a}\end{array}$ & $\begin{array}{c}\text { Compressive strength } \\
\text { parallel to the grain of } \\
\text { wood grain/MPa }\end{array}$ & $\begin{array}{c}\text { Flexural } \\
\text { strength } \\
/ \mathbf{M P a}\end{array}$ & $\begin{array}{c}\text { Elastic } \\
\text { modulus } \\
/ \mathbf{M P a}\end{array}$ & $\begin{array}{c}\text { Shear strength along } \\
\text { grain } \\
/ \mathbf{M P a}\end{array}$ \\
\hline L. gmelinii & 0.67 & 13.67 & 129.03 & 57.6 & 113.3 & 12053 & \\
\hline
\end{tabular}

Table 2. Physical and mechanical properties of structural adhesive

\begin{tabular}{c|c|c|c|c|c|c}
\hline Material & $\begin{array}{c}\text { Solid content } \\
/ \%\end{array}$ & $\begin{array}{c}\text { Shear strength } \\
/ \mathbf{M P a}\end{array}$ & $\begin{array}{c}\text { Tensile strength } \\
/ \mathbf{M P a}\end{array}$ & $\begin{array}{c}\text { Compressive } \\
\text { strength } \\
/ \mathbf{M P a}\end{array}$ & $\begin{array}{c}\text { Wood breakage } \\
\text { rate } \\
/ \%\end{array}$ & $\begin{array}{c}\text { Elastic modulus } \\
/ \mathbf{M P a}\end{array}$ \\
\hline $\begin{array}{c}\text { Water-based } \\
\text { polyurethane structural } \\
\text { adhesive }\end{array}$ & $58 \pm 3$ & $\geq 10$ & $\geq 40$ & $\geq 75$ & $\geq 70$ \\
\hline
\end{tabular}


Table 3. Parameters of the glulam T-beam

\begin{tabular}{c|c|c|c|c|c|c|c|c}
\hline $\begin{array}{c}\text { Specimen } \\
\text { grouping }\end{array}$ & $\begin{array}{c}\text { Number } \\
\text { of test } \\
\text { pieces }\end{array}$ & $\begin{array}{c}\text { Specimen } \\
\text { number }\end{array}$ & $\begin{array}{c}\text { Length } \\
\text { /mm }\end{array}$ & $\begin{array}{c}\text { Flange } \\
\text { width } \\
\text { /mm }\end{array}$ & $\begin{array}{c}\text { Flange } \\
\text { height } \\
\text { /mm }\end{array}$ & $\begin{array}{c}\text { Web } \\
\text { width } \\
\text { /mm }\end{array}$ & $\begin{array}{c}\text { Web } \\
\text { height } \\
\text { /mm }\end{array}$ & $\begin{array}{c}\text { Shear } \\
\text { span } \\
\text { ratio }\end{array}$ \\
\hline A & 2 & A1, A2 & 1400 & 250 & 60 & 70 & 180 & 2.5 \\
B & 2 & B1, B2 & 1400 & 250 & 60 & 60 & 180 & 2.5 \\
C & 2 & C1, C2 & 1400 & 250 & 60 & 80 & 180 & 2.5 \\
D & 2 & D1, D2 & 1160 & 250 & 60 & 70 & 180 & 2 \\
E & 2 & E1, E2 & 1640 & 250 & 60 & 70 & 180 & 3 \\
F & 2 & F1, F2 & 1400 & $\sim$ & $\sim$ & 70 & 180 & 3.3 \\
\hline
\end{tabular}

\subsection{Test Method}

The test was conducted in the Civil Engineering Structure Laboratory of Central South University of Forestry and Technology. The layout of test equipment and measuring points is shown in Fig. 2. The support is $100 \mathrm{~mm}$ away from the beam end. The concentrated load method was used in this test to improve the probability of shear failure. Given the large load, a steel plate with an area not less than 100 $\mathrm{cm}^{2}$ was added at the loading point to ensure no local bearing failure at the loading point. A grid of $30 \times 30 \mathrm{~mm}$ was drawn on one side of the beam to observe the occurrence of shear failure. When the vertical line is broken, the shear failure along the grain is proven; when the horizontal line is broken, the shear failure perpendicular to the grain is proven. A loading reaction frame and a hydraulic jack were used for grading loading in the test. A $100 \mathrm{t}$ pressure sensor was placed under the jack to control the loading of each stage. The dividing line of grading was $65 \%$ and $100 \%$ of the theoretical limit load. Before $65 \%$ of the limit load, the load was $3 \mathrm{kN}$ per stage; between $65 \%$ and $100 \%$, the load was $2 \mathrm{kN}$ per stage; after reaching the theoretical limit load, the load was $1 \mathrm{kN}$ per stage. The loading time of each stage was $1 \mathrm{~min}$, and the pressure was stabilized for 1 min after loading. An electronic displacement meter with a measuring range of $10 \mathrm{~cm}$ was set at the bottom of the mid-span of the beam to measure the deflection of the member during the test. A strain flower composed of three strain gauges with $45^{\circ}$ angle among one another was pasted at the midpoint of the loading point and the support point to measure the main strain at the beam web and explore the strain of the component in the test process. A vertical strain gauge was bonded at $150 \mathrm{~mm}$ from the support to measure the longitudinal shear stress. Four strain gauges were bonded along the height direction of the section at the mid-span of the beam, and measuring points 1 and 2 were arranged on the upper and lower sides of the neutral axis, respectively. For the accuracy of the data, measuring points $1^{\prime}$ and $2^{\prime}$ were symmetrically arranged at the same position on the upper and lower sides of the central axis on the other side of the beam. Five strain gauges were uniformly pasted on the upper surface of the flange at the midpoint of the loading point and the support point of the Tbeam along the width direction of the flange plate. All test data were collected synchronously by using a DH3821 static strain gauge.

To ensure the uniform stress of the timber beam and prevent the lateral instability during the loading, the straightness of the timber beam was measured with a spirit level before the test, and the loading and center points of the timber beam were aligned using a plumb bob. Each component was preloaded twice before the formal test to ensure the normal operation of the instrument and eliminate the poor contact among the supports. The preloading load of each component was $10 \%$ of the theoretical limit load, and the preloading time was 5 min.

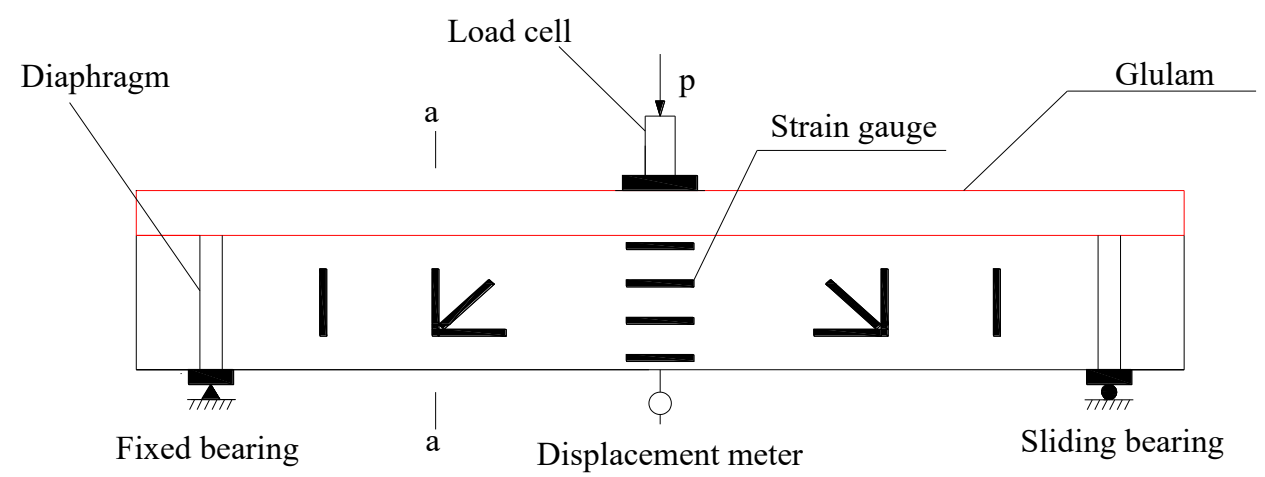

a) Loading layout of components

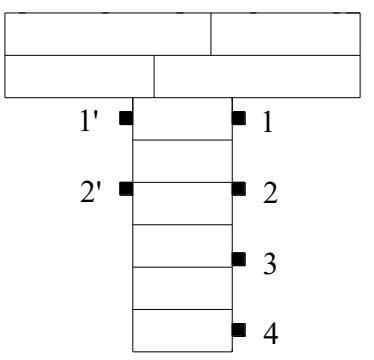

b) Arrangement of strain-measuring points in the mid-span section of the T-beam (mm)
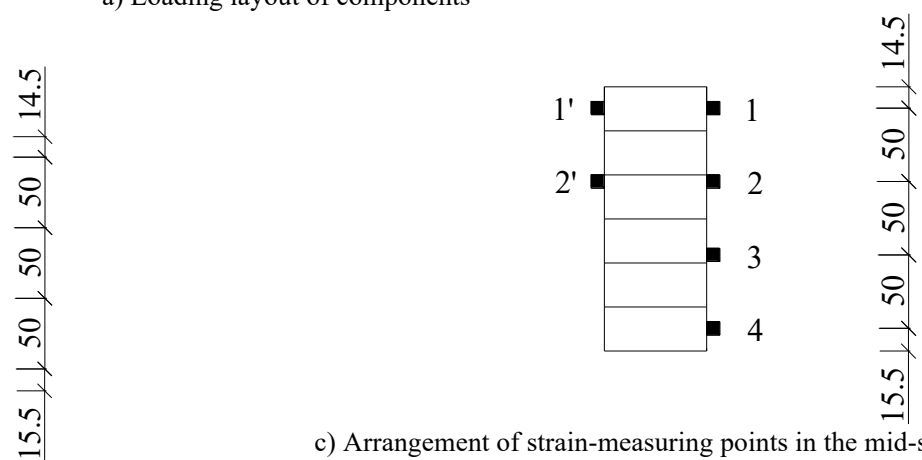

c) Arrangement of strain-measuring points in the mid-span section of the rectangular beam $(\mathrm{mm})$ 


$$
14.5,58.5,52,52,58.5,14.5
$$
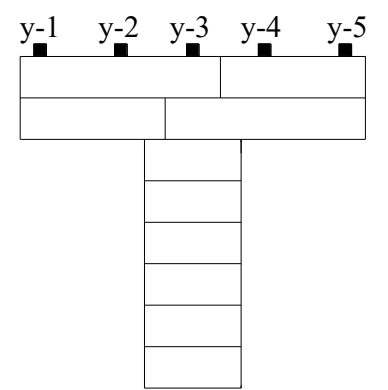

d) Arrangement of strain-measuring points on a-a section (mm)

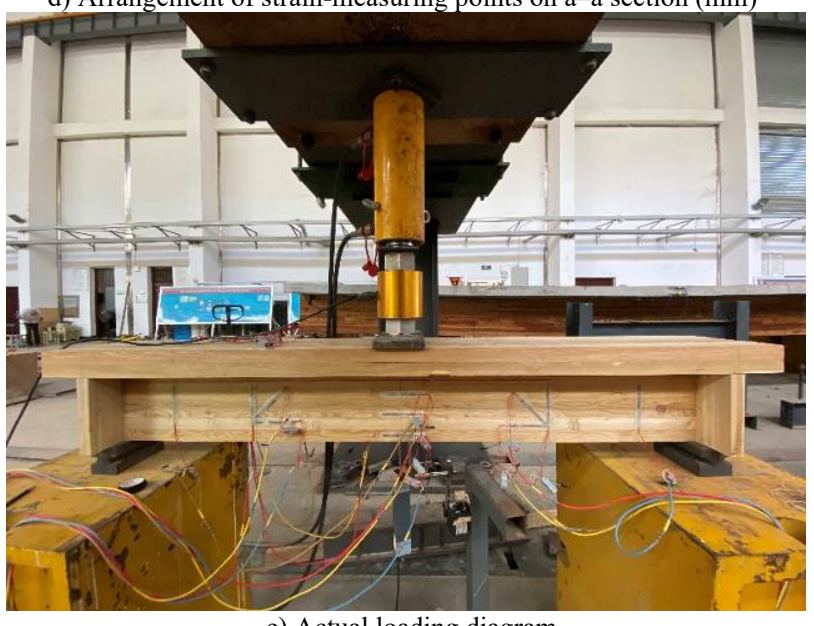

e) Actual loading diagram

Fig. 2. Test loading and strain-measuring point arrangement (mm)

\section{Result Analysis and Discussion}

\subsection{Failure mode and mechanism analysis}

In the test, the failure conditions of each group of glulam beams are similar. At the beginning of loading, T-beams and rectangular beams are in the elastic stage. When the load is increased to $75 \%-90 \%$ of the ultimate load, the glulam beams begin to emit crisp and tear sound. The sound mainly comes from the position of the web under the loading point and the position of the flange end. Small initial cracks are observed at the middle of the web under the loading point, and evident cracks are identified at the junction of the web and the flange at the ends of A2, C2, and E1 beams. As the load continues to increase, the cracks at the flange continue to expand, and the initial cracks on the web continue to expand and gradually develop to the beam end. The plastic characteristics of the timber beam become increasingly intense. The timber is compressed at the support and the loading point; a slight plastic deformation exists, but no local compression failure occurs. When a component reaches the ultimate load, the glulam beam emits a loud noise, and the bearing capacity is reduced to approximately $65 \%$ of the ultimate bearing capacity. All the glulam beams produce an interlaminar dislocation, and evident shear failure cracks appear at the junction of flange and web at the end of A1, A2, B1, C2, D2, and E1 beams. Shear failure occurs in the glulam beams. No obvious sign exists before the failure of the component, which belongs to brittle failure. The beam web produces a crack from the middle of the beam span to the end of the beam. No wood breakage exists at the beam bottom. The interlaminar dislocation mainly occurs among the woods, and bonding surface slip does not occur in the components. Accordingly, the bonding strength reaches the requirement. Typical failure patterns are shown in Fig. 3.

Mechanism analysis: the failure modes of 12 beams are typical shear failure along the grain. The bending deformation of glulam beams occurs under the action of concentrated load. Under the combined action of shear and bending moment, a member produces the maximum bending stress in the middle of the span and the maximum shear stress near the neutral axis in the middle of the span. However, the bending strength of the component is greater than the shear strength because the tensile and compressive strength of wood along the grain is much higher than the shear strength of wood along the grain and the shear span of the component is relatively small. Under the action of comprehensive stress, the shear stress in the middle part of the component first reaches the limit value, and the initial crack is formed in the weak part. With the increase in load, the crack continues to develop, and shear failure along grain finally occurs. Shear cracks are mainly located in the lower part of the neutral axis because the deflection of the component is increasing under the action of concentrated load, the volume of wood is compressed, the cross-sectional area is reduced, and the compressive strength of wood is lower than the tensile strength. Consequently, the compression zone will yield before the tensile zone, resulting in the gradual downward migration of the neutral axis, and the maximum shear stress zone will also move downward; the final shear cracks are located in the lower side of the neutral axis. The reason why the cracks are not through and mainly located at one end of the fixed hinge bearing is that the constraints at both ends are incompletely symmetrical. The deformation and displacement of the beam are also incompletely symmetrical; hence, the stress distribution is incompletely symmetrical. The shear stress at the end of fixed support is greater than that at the end of sliding support; as a result, the shear crack is located at the end of fixed support.

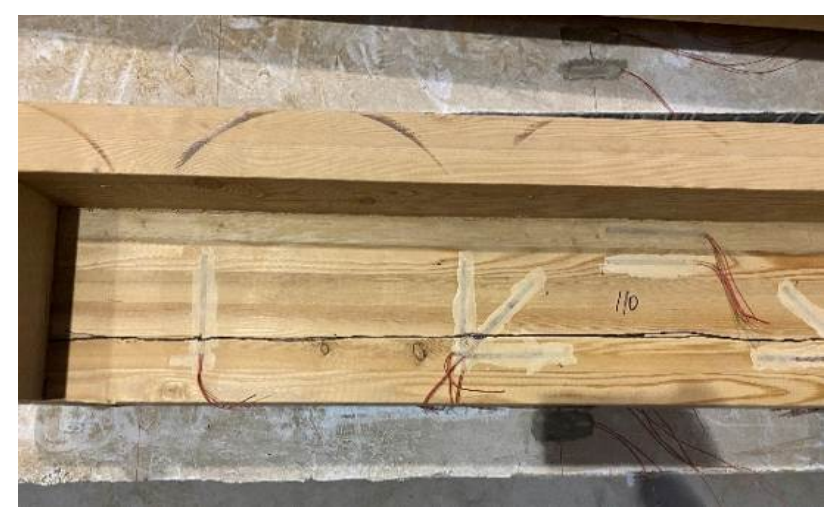

a) A1

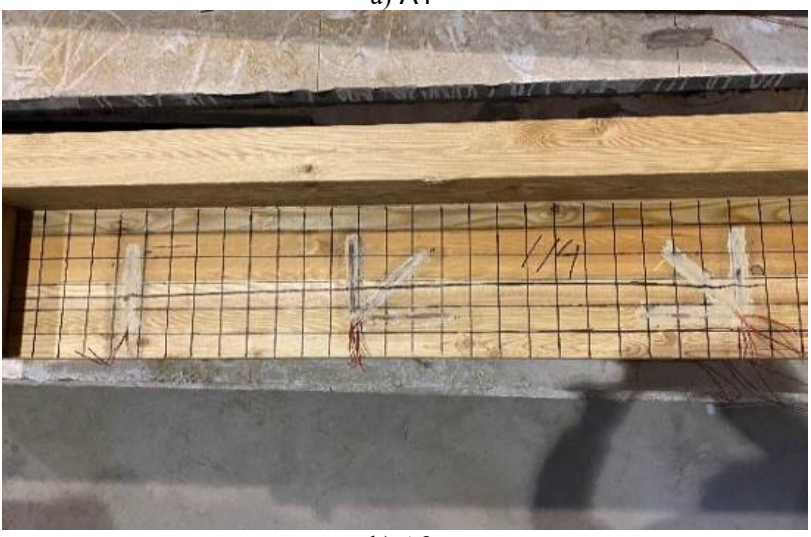

b) A2 


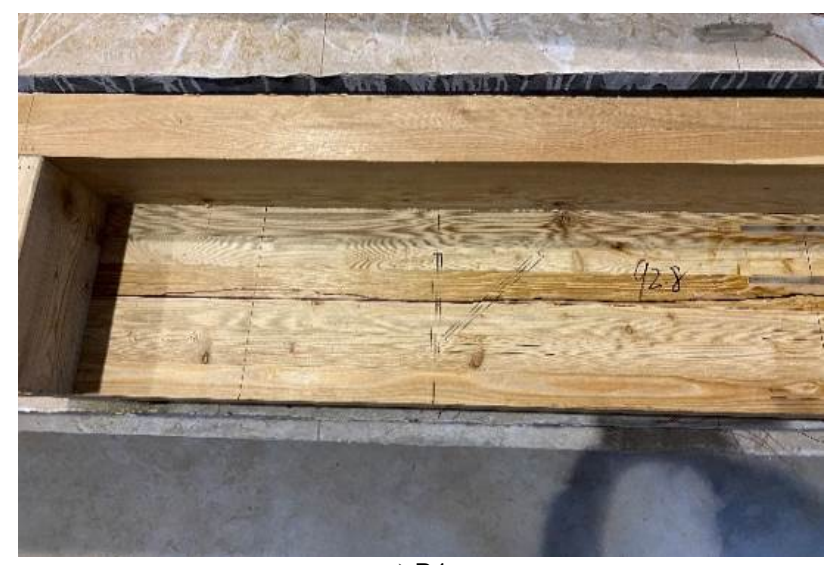

c) B1

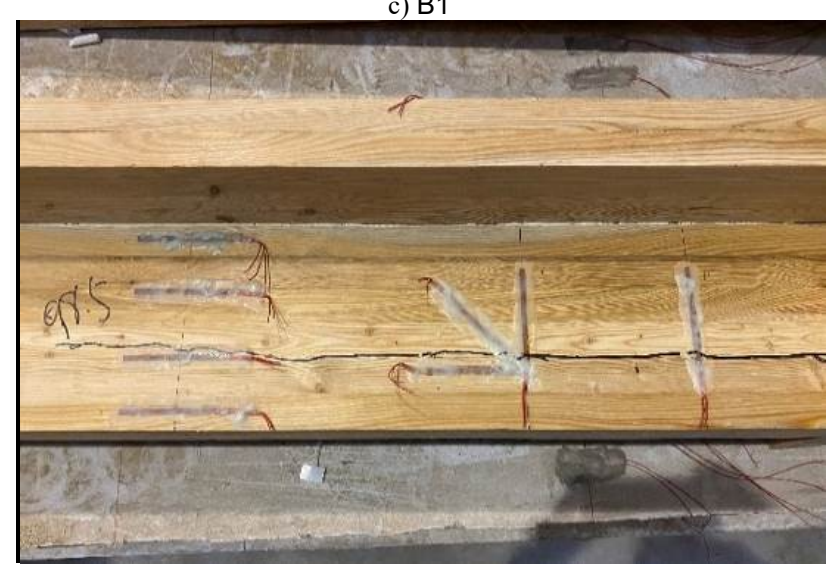

d) B2

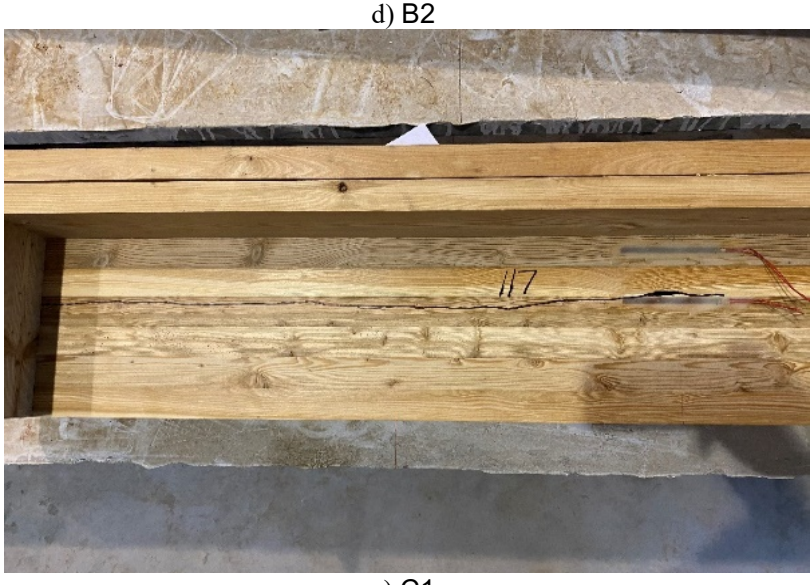

e) C1

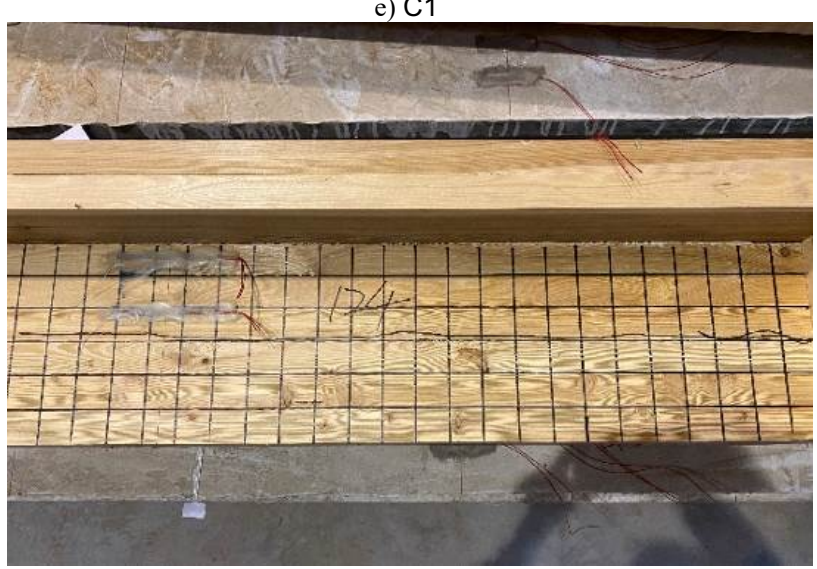

f) $\mathrm{C} 2$

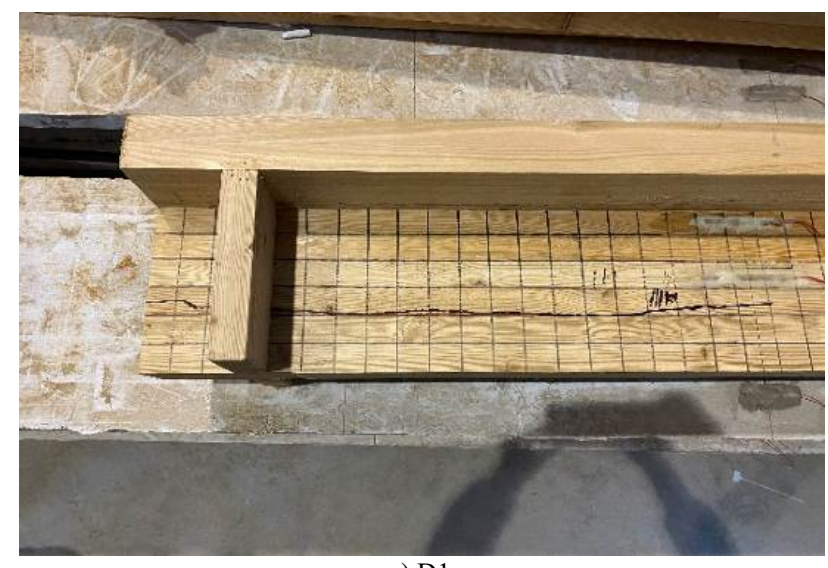

g) D1

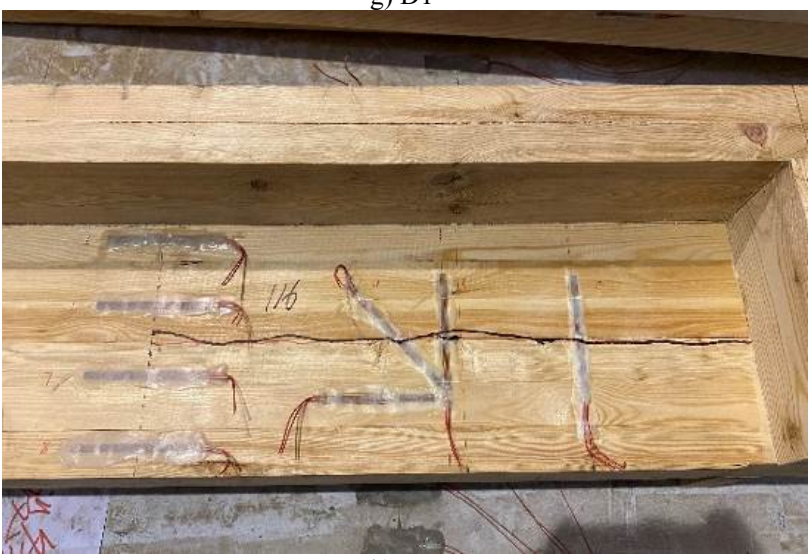

h) D2

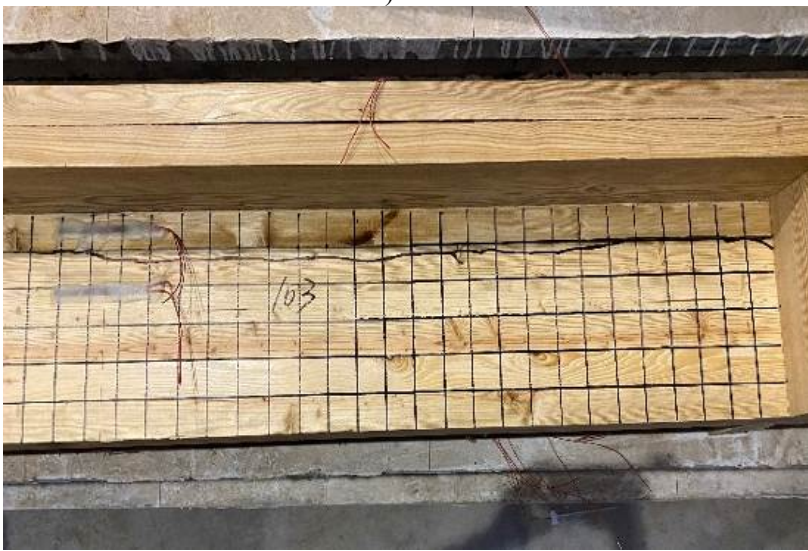

i) E1

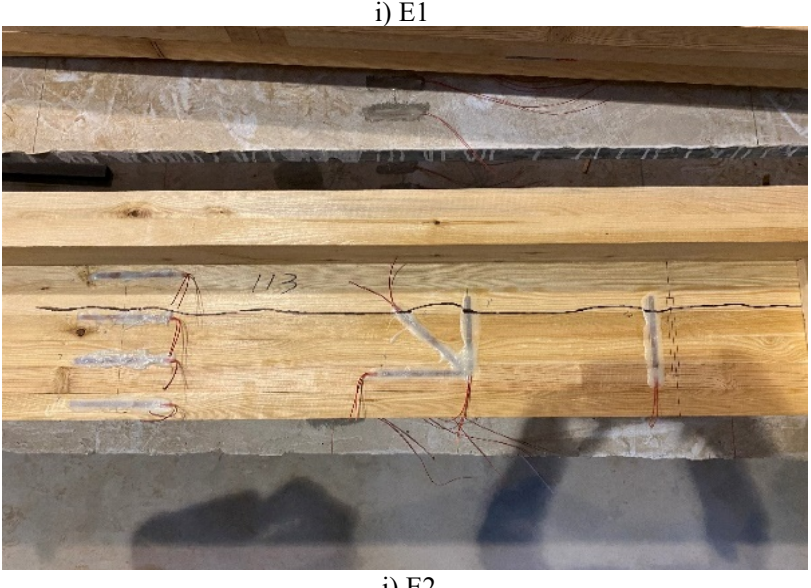

j) E2 


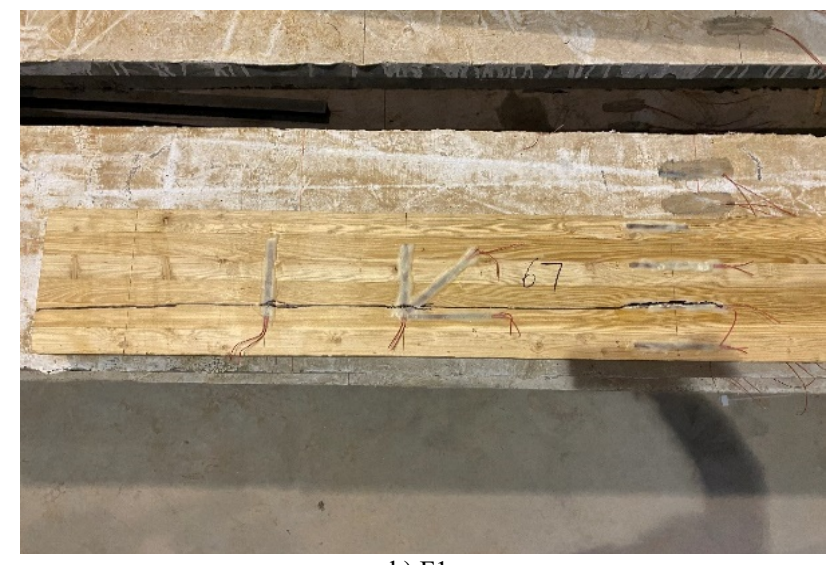

k) F1

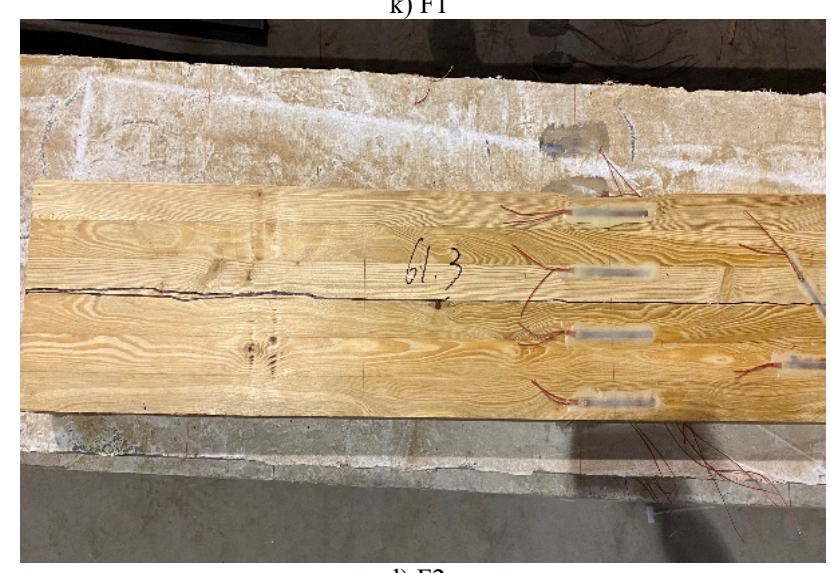

1) F2

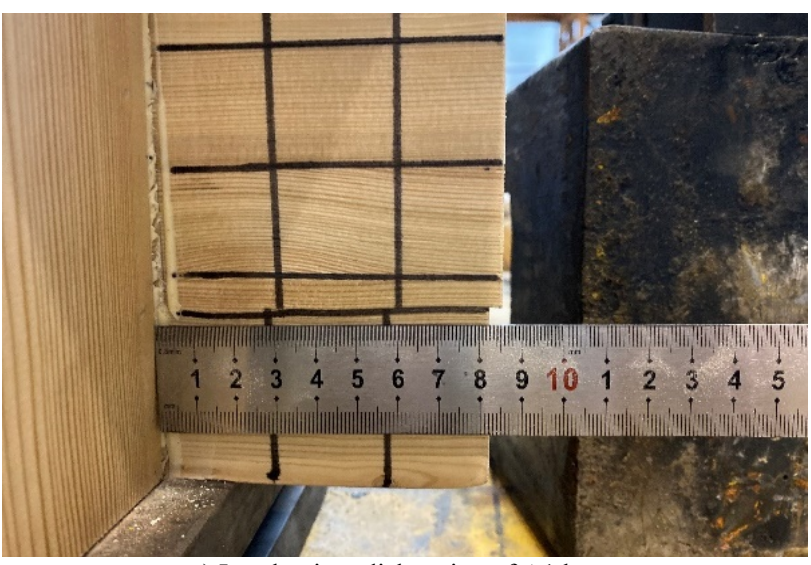

m) Interlaminar dislocation of A1 beam

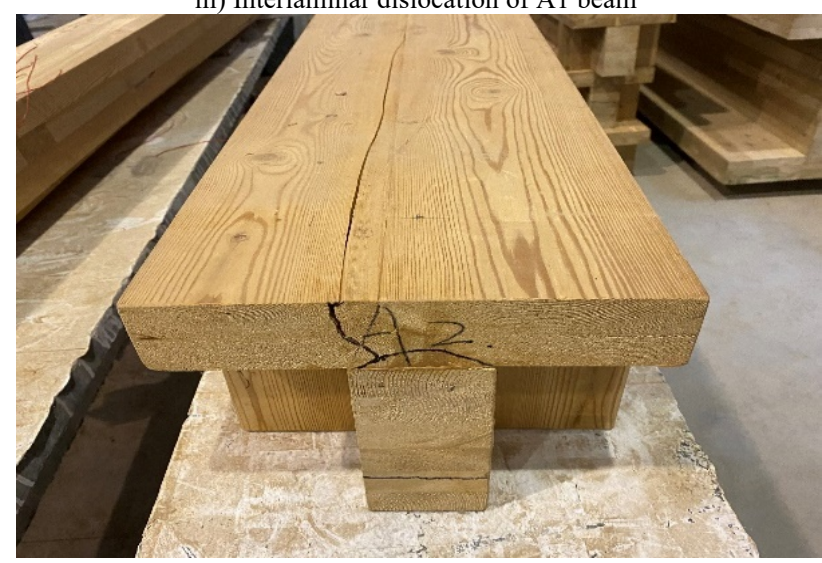

n) Flange damage of A2 beam

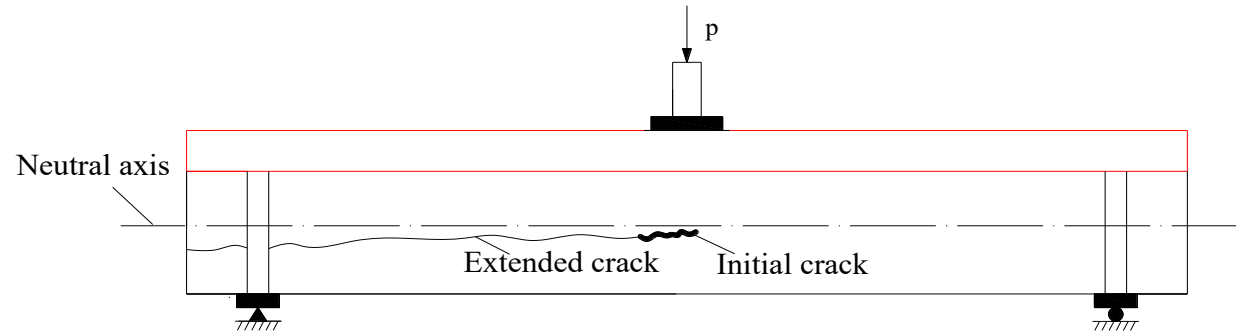

o) Crack development diagram of a glulam beam

Fig. 3. Typical failure modes of glulam beams

\subsection{Load-deflection curve}

The load-deflection curve of mid-span and mechanical property test data of each component are shown in Fig. 4 and Table 4, respectively. Fig. 4 depicts that the variation trend of load-deflection curves of each group of glulam T-beams are basically consistent, which can be obviously divided into two stages. At the initial stage of loading, the curve increases linearly, and the slope of the same group of members is basically the same. In this stage, the load and deflection are small, the section area of the component is almost unchanged, and the component is in the elastic stage. With the increase in load, the mid-span deflection of the component increases gradually, the wood volume is compressed, the section area decreases, and the slope of the curve decreases gradually. The load-deflection curve shows evident plastic characteristics, and the component enters the elastic-plastic stage. The curve slope change point is defined as the yield point of the component.

The test values (average) of the mechanical properties of each group of glulam beams are shown in Table 5, in which the bending stiffness is calculated in accordance with the secant slope of $0.1 \mathrm{P}_{\max }$ and $0.4 \mathrm{P}_{\max }\left(\mathrm{P}_{\max }\right.$ is the ultimate load) on the load-deflection curve [23]. Table 5 indicates that the ultimate bearing capacity and bending stiffness of the glulam
T-beam are much higher than those of the glulam rectangular beam. Compared with the glulam rectangular beam, the ultimate bearing capacity of the glulam T-beam increases by $71.36 \%$ on average, and the bending stiffness increases by $131.28 \%$ on average. Comparison of the results of groups A, B, and C (test group 1) shows that the ultimate bearing capacity of group $C$ is highest, whereas that of group $\mathrm{B}$ is lowest. The ultimate bearing capacity of group $\mathrm{C}$ is $26 \%$ higher than that of group $\mathrm{B}$ and $7.6 \%$ higher than that of group A. The bending stiffness of group A is the highest, whereas that of group B is the lowest. The bending stiffness of group A is $41.2 \%$ higher than that of group B and $30.8 \%$ higher than that of group C. In accordance with test group 1, with the increase in the web thickness of the glulam T-beam, the section area and effective shear area of the member increase, and the shear capacity also increases. Comparison of the results of groups A, D, and E (test group 2) demonstrates that the ultimate bearing capacity of group $\mathrm{D}$ is the highest, whereas that of group $\mathrm{E}$ is the lowest. The ultimate bearing capacity of group D is $5.1 \%$ higher than that of group $\mathrm{E}$ and $1.34 \%$ higher than that of group A. The bending stiffness of group D is the highest, whereas that of group $\mathrm{E}$ is the lowest. The bending stiffness of group D is increased by $5.8 \%$ compared with that of group A and $77.6 \%$ compared with that of group E. Test group 2 shows 
that with the increase in shear span ratio, the shear capacity and bending stiffness of glulam T-beam gradually decrease, the nonlinear characteristics of the curve gradually weaken, and the plastic stage is increasingly obvious. Comparison of the results of test groups 1 and 2 indicates that the change in web width has a great influence on the shear ultimate bearing capacity of beams, and the change in shear span ratio has a great influence on the flexural stiffness of members.

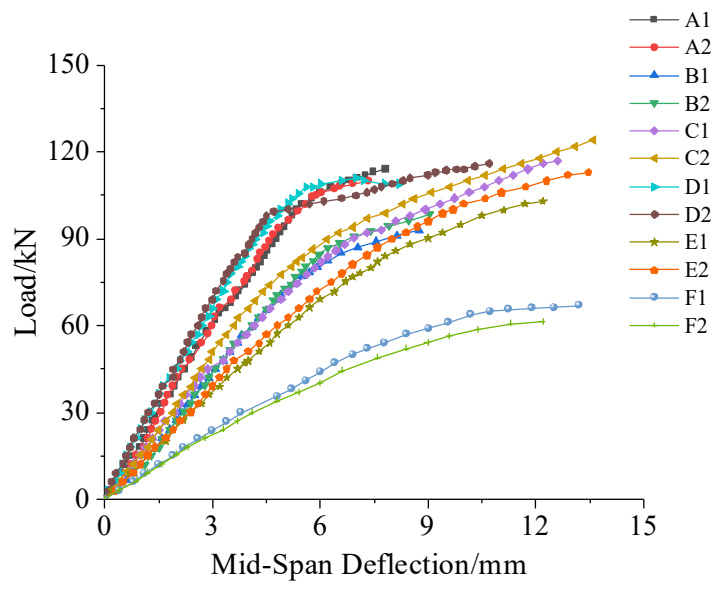

Fig. 4. Load-deflection curve of the mid-span

Table 4. Test results of the mechanical properties of members

\begin{tabular}{c|c|c|c|c|c|c}
\hline Specimen & $\begin{array}{c}\text { Yield } \\
\text { load } \\
\text { /kN }\end{array}$ & $\begin{array}{c}\text { Yield } \\
\text { displacement } \\
\text { /mm }\end{array}$ & $\begin{array}{c}\text { Ultimate } \\
\text { load } \\
\text { /kN }\end{array}$ & $\begin{array}{c}\text { Limit } \\
\text { displacement } \\
\text { /mm }\end{array}$ & $\begin{array}{c}\text { Shear } \\
\text { span } \\
\text { ratio }\end{array}$ & $\begin{array}{c}\text { Cross- } \\
\text { sectional } \\
\text { area } \\
\text { /mm }\end{array}$ \\
\hline A1 & 102 & 5.492 & 114 & 7.822 & 2.5 & 27600 \\
A2 & 106 & 6.016 & 110 & 7.355 & & \\
\hline B1 & 80.1 & 5.9 & 92.8 & 8.76 & 2.5 & 25800 \\
B2 & 86.7 & 6.2 & 98.5 & 9.05 & & \\
\hline C1 & 90.3 & 6.94 & 117 & 12.61 & 2.5 & 29400 \\
C2 & 94.1 & 6.9 & 124 & 13.6 & & \\
\hline D1 & 107.7 & 5.6 & 111 & 8.2 & 2 & 27600 \\
D2 & 100.2 & 5.1 & 116 & 10.7 & & \\
\hline E1 & 88.1 & 8.5 & 103 & 12.2 & 3 & 27600 \\
E2 & 98.7 & 9.4 & 113 & 13.47 & 3 & \\
\hline F1 & 54 & 7.8 & 67 & 13.21 & 3.3 & 12600 \\
F2 & 49 & 7.6 & 61.3 & 12.2 & & \\
\hline
\end{tabular}

Table 5. Average value of the mechanical property test results of members

\begin{tabular}{c|c|c|c|c|c}
\hline $\begin{array}{c}\text { Specimen } \\
\text { group }\end{array}$ & $\begin{array}{c}\text { Yield } \\
\text { load } \\
\text { /kN }\end{array}$ & $\begin{array}{c}\text { Yield } \\
\text { displacement } \\
\text { /mm }\end{array}$ & $\begin{array}{c}\text { Ultimate } \\
\text { load } \\
/ \mathbf{k N}\end{array}$ & $\begin{array}{c}\text { Limit } \\
\text { displacement } \\
/ \mathbf{m m}\end{array}$ & $\begin{array}{c}\text { Bending } \\
\text { stiffness } \\
/ \mathbf{N} \cdot \mathbf{m m}^{-1}\end{array}$ \\
\hline $\mathrm{A}$ & 104 & 5.755 & 112 & 7.5885 & 21566 \\
$\mathrm{~B}$ & 83.4 & 6.05 & 95.65 & 8.905 & 15274 \\
$\mathrm{C}$ & 92.2 & 6.92 & 120.5 & 13.105 & 16486 \\
$\mathrm{D}$ & 103.95 & 5.35 & 113.5 & 9.45 & 22808 \\
$\mathrm{E}$ & 93.4 & 8.95 & 108 & 12.835 & 12839 \\
$\mathrm{~F}$ & 51.5 & 7.7 & 64.15 & 12.705 & 7694 \\
\hline
\end{tabular}

\subsection{Load-strain curve}

Four strain gauges are arranged along the cross-section height direction in the mid-span of T-beam and rectangular beam of glulam (Fig. 2), numbered from top to bottom as 1 , 2, 3, and 4. Measuring points 1 and 2 are located on the upper and lower sides of the theoretical neutral axis. To ensure the accuracy of the data, the two other measuring points 1 ' and 2 ' are arranged symmetrically on the other side of the component, and the average strain values of the two symmetrical positions are regarded as the result. The strain is positive under tension and negative under compression. The load-strain curve is shown in Fig. 5.

Fig. 5 depicts that the strain variation of each group of glulam beams in the mid-span section generally shows a similar law. At the initial stage of loading, the members are in the elastic stage, and the curve increases linearly, which conforms to the plane section assumption. With the increase in load, the members enter the elastic-plastic stage, the compression side presents evident nonlinear characteristics and the tension side changes in accordance with the linear law. The compressive strength of wood is much lower than the tensile strength, and the yield occurs in the compression zone before the tensile zone. When the component reaches the failure load, the tensile performance of the wood on the tensile side is inadequately exerted.

The No. 2 measuring point of the glulam T-beam and the No.3 measuring point of the rectangular beam are located at the lower side of the theoretical neutral axis, which is close to the neutral axis. The strain change of the measuring point in the elastic stage is very small, and the slope of the loadstrain curve is large, which conforms to the neutral axis theory. With the increase in load, the component enters the elastic-plastic stage, the slope of the curve increases gradually, and the final strain changes from tensile strain to compressive strain. When the slope of load-strain curve of the No.2 measuring point of the glulam T-beam increases, the slope of the No.3 measuring point curve also increases gradually. This result is consistent with the analysis in 4.1 . When the component enters the elastic-plastic stage, with loading, the deflection increases, the section area decreases, and the neutral axis moves downward. Finally, the component is destroyed, and the failure position is located at the lower side of the theoretical neutral axis.

Comparison of the load-strain curves of groups A, B, and $\mathrm{C}$ shows that under the same load, the strain of group $\mathrm{B}$ is the largest, whereas the strain of group $C$ is the smallest. This result confirms from the perspective of strain that increasing the section area of the component can improve the bearing capacity and bending stiffness of the glulam Tbeam. Comparison of the load-strain curves of groups A, D, and $\mathrm{E}$ indicates that under the same load, the strain of group $\mathrm{D}$ is the largest, whereas that of group $\mathrm{E}$ is the smallest. Accordingly, increasing the shear span ratio will reduce the bearing capacity and bending stiffness of the glulam T-beam. Comparison of the load-strain curves of the glulam T-beam and rectangular beam demonstrates that the mechanical properties of the glulam T-beam are greatly improved compared with those of the rectangular beam.

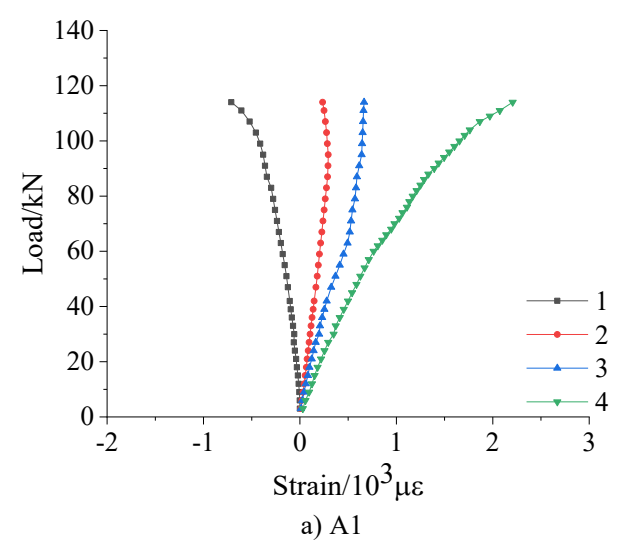




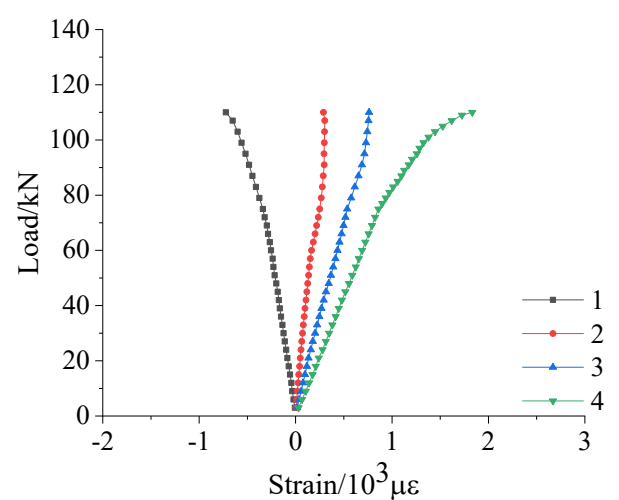

b) $\mathrm{A} 2$

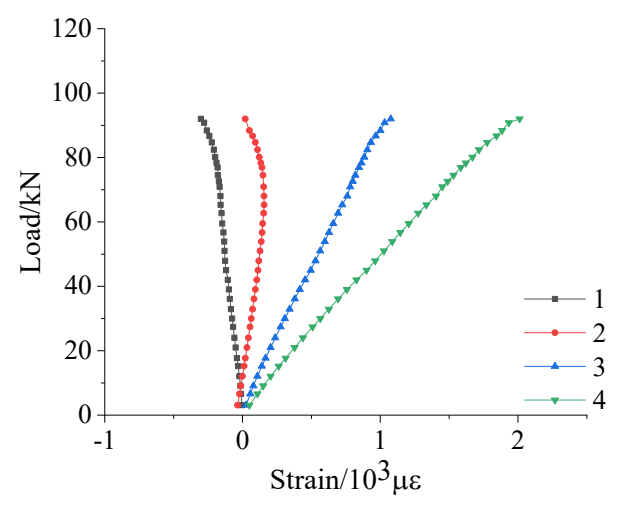

c) $\mathrm{B} 1$

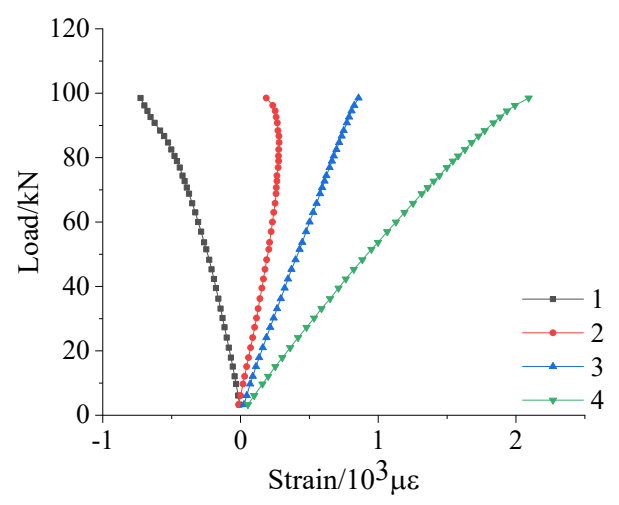

d) $\mathrm{B} 2$

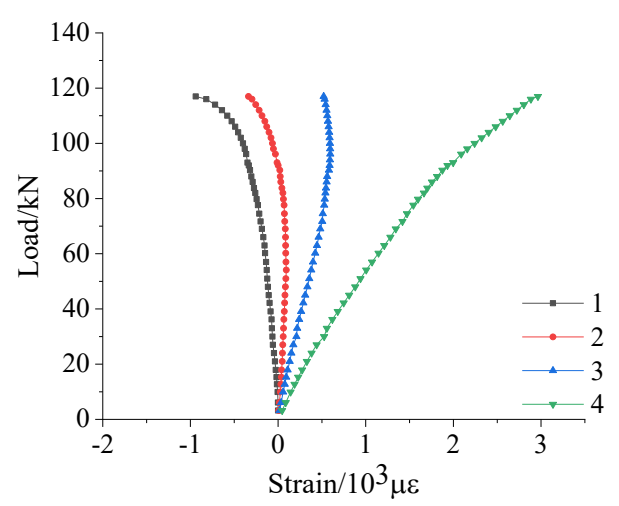

e) $\mathrm{C} 1$

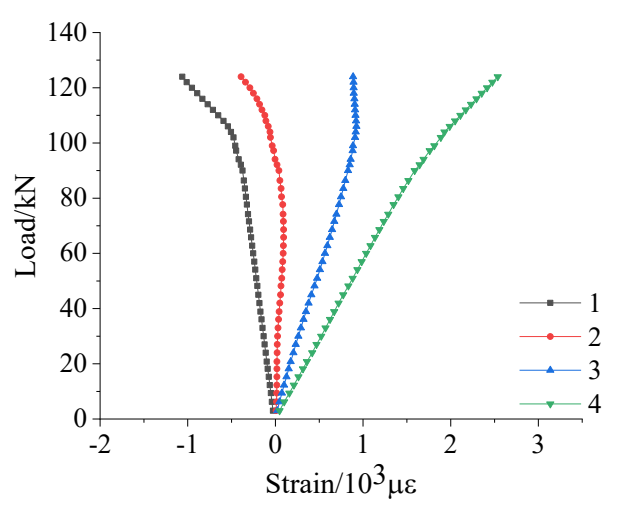

f) $\mathrm{C} 2$

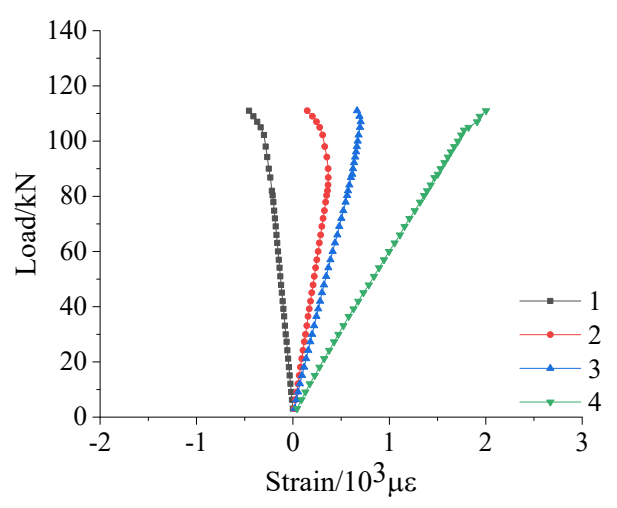

g) D1

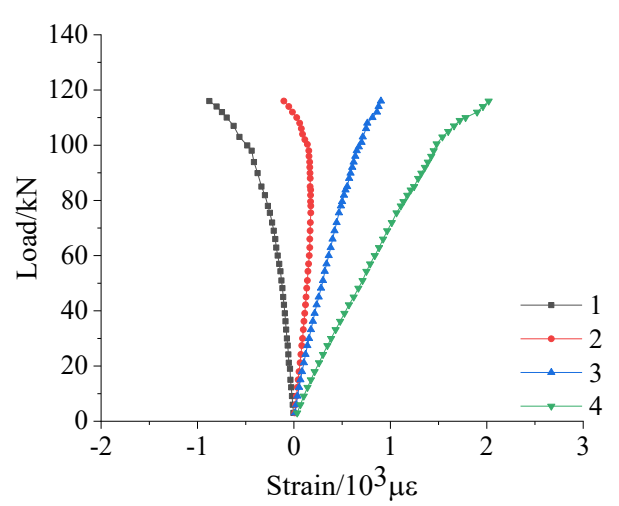

h) D2

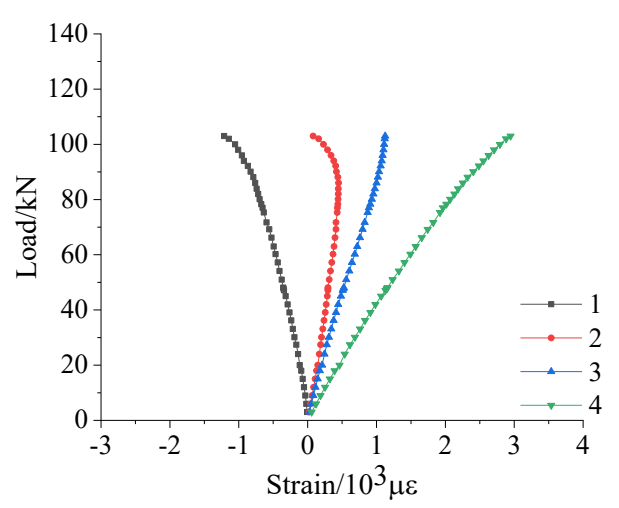

i) $\mathrm{E} 1$ 


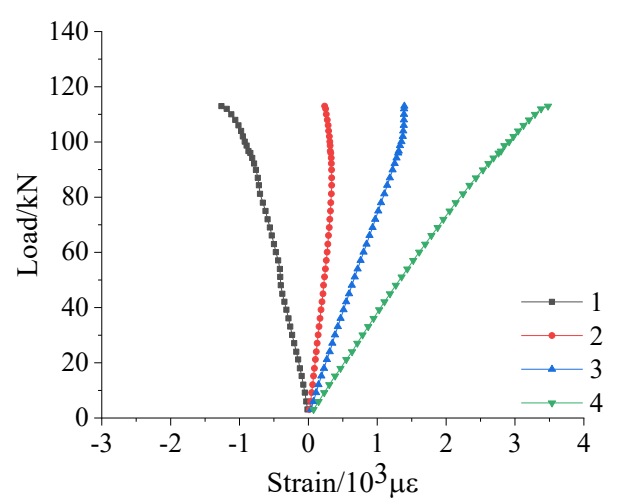

j) $\mathrm{E} 2$

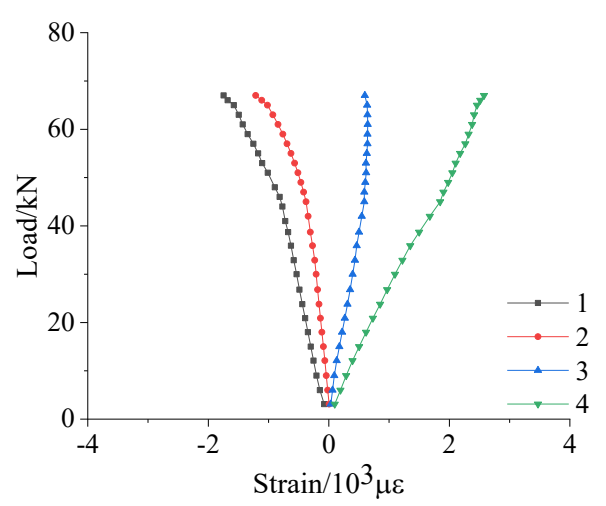

k) F1

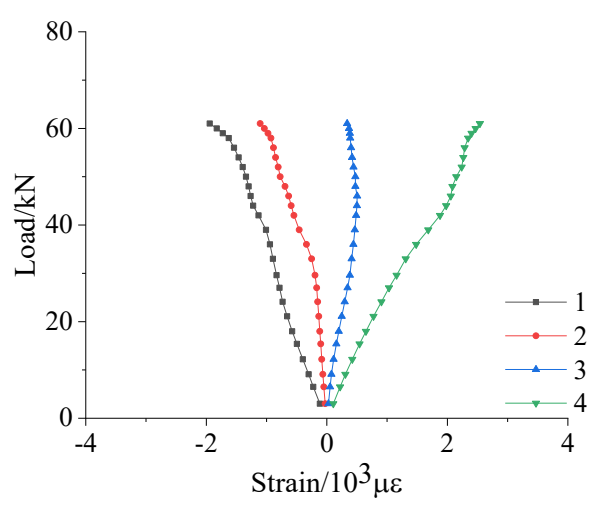

1) $\mathrm{F} 2$

Fig. 5. Load-strain curve of the mid-span section

\subsection{Transverse distribution of flange strain}

During the test of group A members, evident shear failure occurs along the longitudinal direction of the beam at the junction of the web and flange of A2 (Fig. 3n). Therefore, five strain gauges are evenly arranged along the width direction on the upper surface of the flange at the midpoint of the loading and support points of group B, C, D, and E members to measure the strain of the flange during the loading process. Details of the arrangement of measuring points are shown in Fig. 2, and the longitudinal strain distribution along the transverse direction of the flange of the glulam T-beam is shown in Fig. 6.

During the entire test process, different degrees of shear failure occur at the interface of flange and web of A1, A2, $\mathrm{B} 1, \mathrm{C} 2, \mathrm{D} 2$, and $\mathrm{E} 1$ components. In the bending deformation of the glulam T-beam, the shear flow transferred from the web to the flange produces uneven shear deformation in the width direction of the flange, which leads to the uneven distribution of stress in the width direction, the shear lag effect, and the shear failure of the glulam T-beam flange.

Fig. 6 presents that the variation trend of the curves of the same group of members under various loads is basically the same. At the beginning of loading, the load is small, and the curve is approximately a straight line. With the increase in load, the strain distribution along the transverse direction begins to become uneven, and the strain gradually increases from the flange edge to the junction of flange and web and reaches the maximum at the junction. The closer to the central axis of the component is, the smaller the strain is. The minimum strain appears at the central axis position, and the component has evident uneven stress distribution. With the increase in load level, the strain of each measuring point increases rapidly. The load increase causes increasingly large compressive stress of the flange, and the wood reaches the compressive strength limit and enters the elastic-plastic stage. Comparison of the strain curves of groups $\mathrm{B}$ and $\mathrm{C}$ shows that the increase in web width has a minimal effect on the changing trend of flange strain. Under the same grade load, the strain value of the group B component is greater than that of the group $\mathrm{C}$ component, and the shear lag effect of the group $\mathrm{C}$ component is more obvious, indicating that increasing web width will strengthen the shear lag effect of the glulam T-beam. Comparison of the strain curves of groups $\mathrm{D}$ and $\mathrm{E}$ demonstrates that the change in shear span ratio has an inconsiderable effect on the changing trend of flange strain. Under the same level of load, the strain value of group $\mathrm{E}$ is much larger than that of group $\mathrm{D}$, and the shear lag effect of group D is more obvious, indicating that increasing shear span ratio will weaken the shear lag effect of the glulam T-beam.

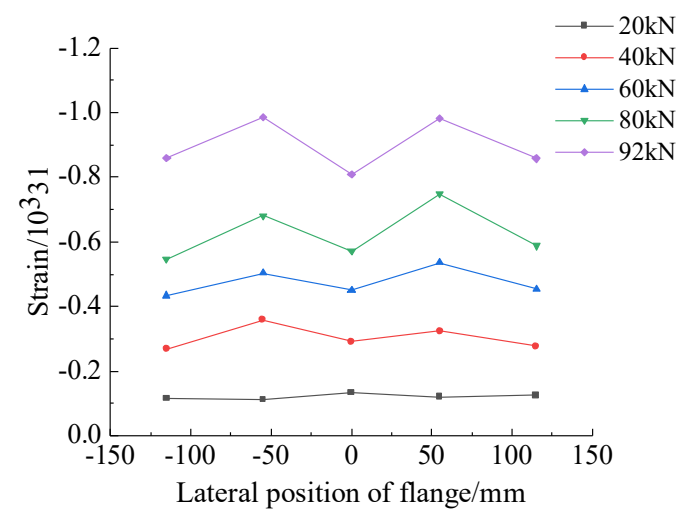

a) B1

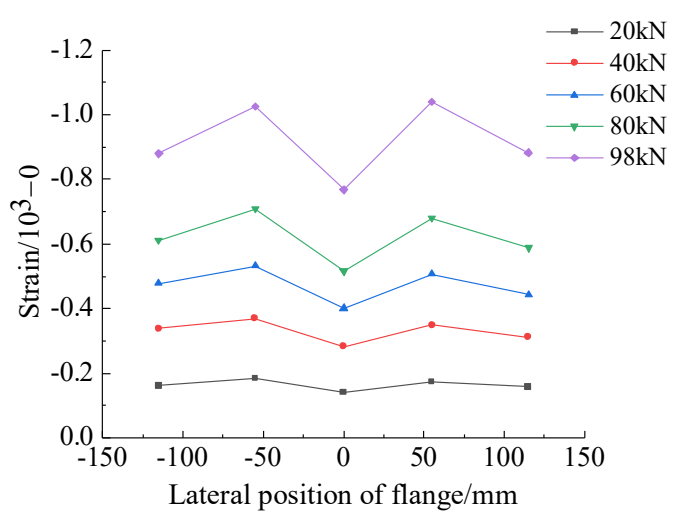

b) $\mathrm{B} 2$ 


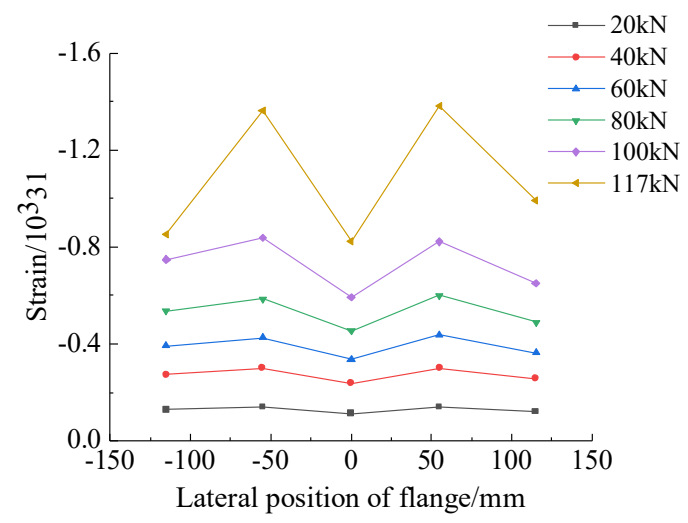

c) $\mathrm{C} 1$

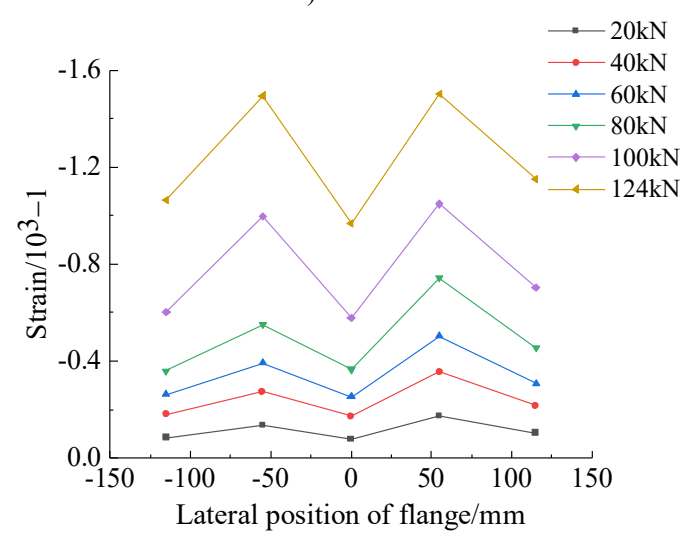

d) $\mathrm{C} 2$

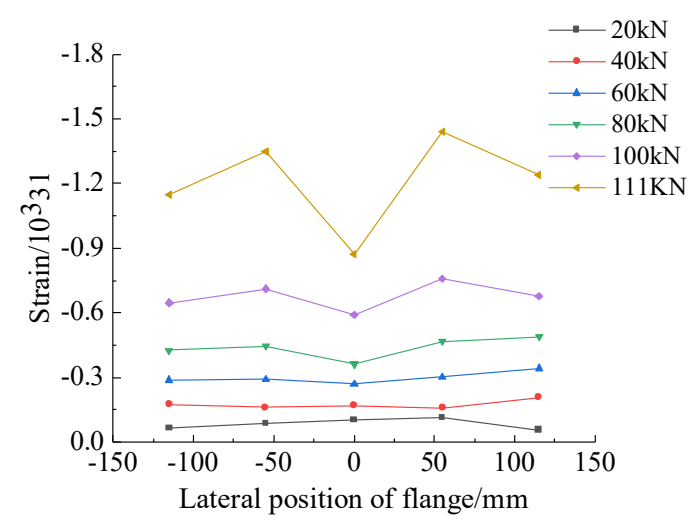

e) D1

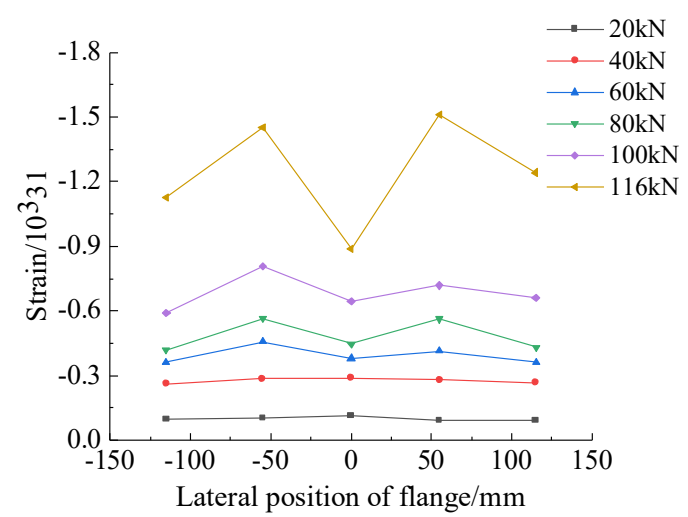

f) D2

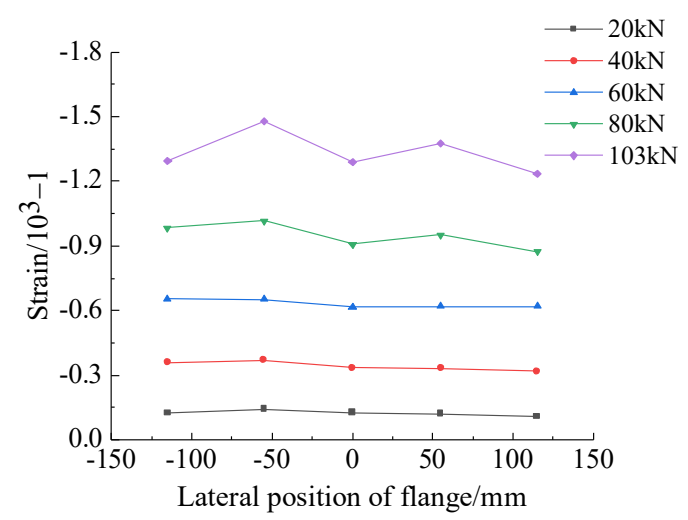

g) E1

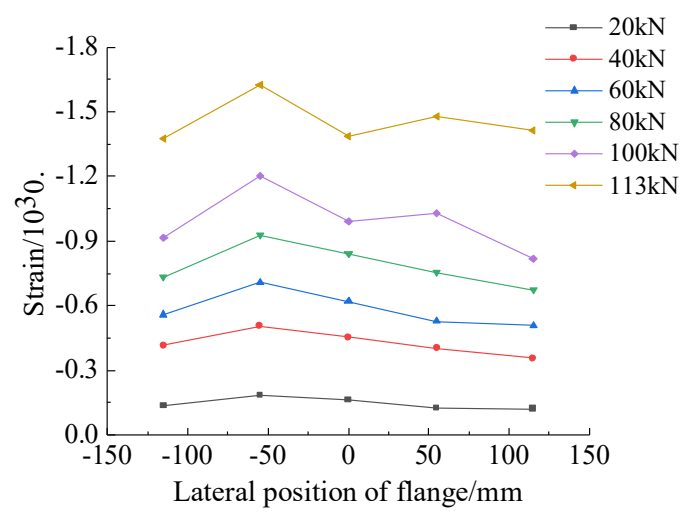

h) E2

Fig. 6. Curve of longitudinal strain distribution along the transverse direction of flange

\subsection{Shear strength analysis of glulam T-beam}

In this test, all components are subjected to shear failure along the grain. The influences of the neutral axis downward and the section deformation are disregarded, and vertical shear stress $\tau$ is produced in the section of the member under concentrated load. In accordance with the reciprocal theorem of shear stress, the shear stress $\tau^{\prime}$ is the same in the longitudinal direction of the beam. The maximum shear stress occurs at the neutral axis of the section; hence, $\tau^{\prime}$ reaches the maximum at the central axis. When $\tau^{\prime}$ exceeds the shear strength along the grain, shear failure occurs. The shear stress $\tau$ of the glulam T-beam and rectangular beam can be obtained using Formula (1):

$\tau=\frac{F_{s} S_{z}}{I_{z} b}$

In this equation, $F_{s}$ is the shear force in the cross section, $I_{z}$ is the inertia moment of the entire cross section to the neutral axis, $S_{z}$ is the static moment of the cross section to the neutral axis, and $b$ is the width of the web.

Rammer and Soltis [5] studied the shear performance of glulam beams, found that the shear strength of glulam beams was related to the effective shear area, and shear block values. In the current study, regression analysis of the test data is conducted, and the calculation formula of the shear strength of glulam beams (Formula 2) is proposed. The theoretical shear strength of glulam T-beams is calculated using Formula (2): 
$\tau_{R}=\frac{1.3 C_{f} \tau_{Q}}{A^{1 / 5}}$

In this equation, $\tau_{R}$ is the shear strength of glulam $\mathrm{T}$ beams. $C_{f}$ is the stress concentration factor to adjust the actual failure strength of wood, in which the value in this study is $2 . \tau_{Q}$ is the shear strength of shear block, in which the shear strength along grain of Larch in this study is 7 $\mathrm{MPa} . \mathrm{A}$ is the area of the beams under shear, which is defined as the length of the beams that generate shear stress in the beam span multiplied by the width of the web. $\mathrm{A}=1_{0} \mathrm{~b}$, where $1_{0}$ is the calculated span length of the component, and $\mathrm{b}$ is the width of the web.

The actual shear strength of glulam T-beams are calculated in accordance with Formula (1), and the theoretical shear strength is calculated in accordance with Formula (2). The results are shown in Table 6. The shear strength test values of glulam T-beams are greater than the theoretical shear strength values, the maximum relative error is $8.5 \%$, the minimum is $0.2 \%$, and the average relative error is $4.8 \%$. These values meet the error requirements of engineering application, indicating that Formula (2) can be used to calculate the shear strength of glulam T-beams. Compared with the shear strength of A, B, and C groups, the shear strength of glulam T-beams decreases with the increase in shear area. Compared with the shear strength of $\mathrm{A}, \mathrm{D}$, and $\mathrm{E}$ groups, the shear strength of glulam T-beams decreases with the increase in the shear span ratio. Comparison of the shear strength of three groups of members $\mathrm{A}, \mathrm{B}$, and $\mathrm{C}$ shows that the shear strength of glulam T-beams decreases with the increase in shear area. Comparison of the shear strength of three groups of members A, D, and E indicates that the shear strength of glulam T-beams decreases with the increase in shear span ratio.

Table 6. Comparison of shear stress values of glulam Tbeams

\begin{tabular}{c|c|c|c|c|c|c}
\hline Component & $\begin{array}{c}\text { Moment } \\
\text { of } \\
\text { inertia } \\
/ \mathbf{m m}^{4}\end{array}$ & $\begin{array}{c}\text { Static } \\
\mathbf{m o m e n t} \\
/ \mathbf{m m}^{3}\end{array}$ & $\begin{array}{c}\text { Shear } \\
\text { area } \\
/ \mathbf{c m}^{2}\end{array}$ & $\begin{array}{c}\text { Theoretical } \\
\text { value of } \\
\text { shear } \\
\text { strength } \\
/ \mathbf{M P a}\end{array}$ & $\begin{array}{c}\text { Test } \\
\text { value of } \\
\text { shear } \\
\text { strength } \\
/ \mathbf{M P a}\end{array}$ & $\begin{array}{c}\text { Relative } \\
\text { error } \\
\mathbf{6} \%\end{array}$ \\
\hline $\mathrm{A}$ & $1.3 \times 10^{8}$ & $8.4 \times 10^{5}$ & 840 & 4.73 & 5.17 & 8.5 \\
$\mathrm{~B}$ & $1.24 \times 10^{8}$ & $7.7 \times 10^{5}$ & 720 & 4.88 & 4.95 & 1.4 \\
$\mathrm{C}$ & $1.49 \times 10^{8}$ & $9.1 \times 10^{5}$ & 960 & 4.61 & 4.60 & -0.2 \\
$\mathrm{D}$ & $1.3 \times 10^{8}$ & $8.4 \times 10^{5}$ & 672 & 4.95 & 5.24 & 5.5 \\
$\mathrm{E}$ & $1.3 \times 10^{8}$ & $8.4 \times 10^{5}$ & 1008 & 4.56 & 4.98 & 8.4 \\
\hline
\end{tabular}

4.6 Analysis of the shear capacity of glulam T-beams

The comparison and analysis of the failure mode and shear strength of each group of components in the test reveal a certain relationship between the shear capacity of glulam Tbeams and shear span ratio, web width, and the shear strength of the shear block. The shear capacity of glulam Tbeams are analyzed theoretically on the basis of the test results.

The results show that the shear capacity of a glulam Tbeam increases with the increase in web width, and shear failure occurs at the lower side of the neutral axis, indicating that whether the shear failure occurs is related to the shear strength of the lower part of the neutral axis of the section. The area under the neutral axis is defined as the effective shear area of the section, which is equal to the product of the web width and the height of the neutral axis. The fitting analysis of the data (Fig. 7) shows that the shear capacity of the glulam T-beam is positively proportional to the effective shear area, and the determination coefficient $R^{2}$ is 0.943 , which has high fitting accuracy. The results also present that the ultimate bearing capacity of the glulam T-beam decreases with the increase in shear span ratio. The fitting analysis of the data (Fig. 8) shows that the shear bearing capacity of the glulam T-beam is inversely proportional to $\lambda^{1 / 5}$, and the determination coefficient $\mathrm{R}^{2}$ is 0.871 , which also has high fitting accuracy. With reference to the calculation formula of the shear bearing capacity of a concrete T-beam [24], the calculation formula of the shear bearing capacity of a glulam T-beam (Formula 3) is proposed:

$V=\frac{X}{\lambda^{1 / 5}} \tau_{Q} b h_{0}$

In this equation, $\mathrm{V}$ is the shear capacity of the glulam $\mathrm{T}$ beam. $\mathrm{X}$ is the undetermined parameter. $\lambda$ is the shear span ratio of the glulam $\mathrm{T}$-beam. $\tau_{\mathrm{Q}}$ is the shear strength along the grain of the shear block, $\tau_{Q}=7 \mathrm{MPa}$. $\mathrm{b}$ is the width of the web, $\mathrm{h}_{0}$ is the height from the neutral axis to the bottom of the web, and $b_{0}$ is the effective shear area of the cross section.

The test data are integrated into Formula (3) to calculate the value of $X$, and the average value of $X$ is 0.87 ; thus, the formula for calculating the shear bearing capacity of a glulam T-beam (Formula 4) is obtained:

$$
V=\frac{0.87}{\lambda^{1 / 5}} \tau_{Q} b h_{0}
$$

The test parameters of each component are integrated into Formula (4) to calculate the theoretical shear capacity of the component. The results are shown in Table 7. The maximum relative error between the experimental and theoretical values of shear capacity of the glulam T-beam is $2 \%$, the minimum is $1.4 \%$, and the average relative error is $1.71 \%$. The results are in good agreement, indicating that the formula for calculating the shear bearing capacity of a glulam T-beam proposed in this study is reasonable. Formula (4) can be used to calculate the shear bearing capacity of glulam T-beams. This formula has reference significance for the shear design of glulam T-beams in engineering.

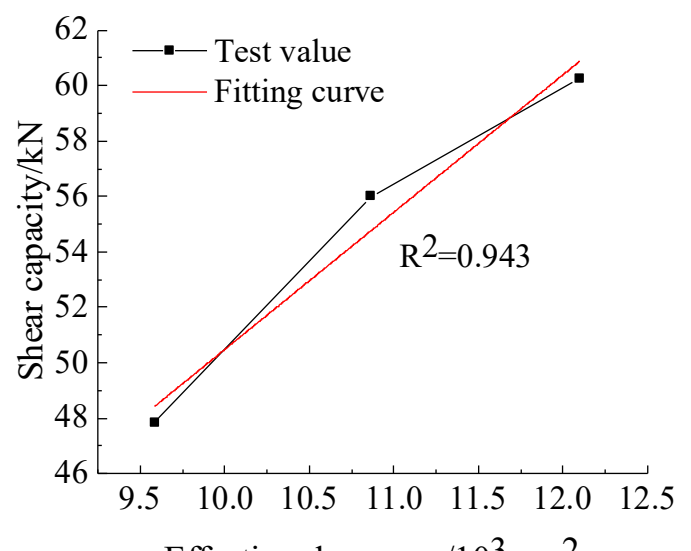

Effective shear area $/ 10^{3} \mathrm{~mm}^{2}$

Fig. 7. Curve of the relationship between shear capacity and effective shear area 


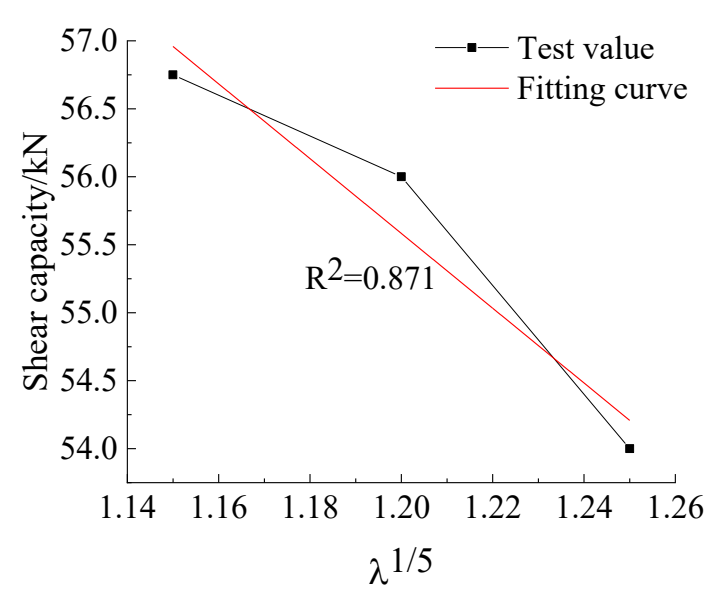

Fig. 8. Curve of the relationship between shear capacity and $\lambda^{1 / 5}$

Table 7. Comparison of the shear capacity of glulam Tbeams

\begin{tabular}{c|c|c|c|c|c}
\hline $\begin{array}{c}\text { Componen } \\
\mathbf{t}\end{array}$ & $\begin{array}{c}\text { Shear } \\
\text { span ratio }\end{array}$ & $\begin{array}{c}\text { Effective } \\
\text { shear area } \\
\text { of section } \\
/ \mathbf{m m}^{\mathbf{2}}\end{array}$ & $\begin{array}{c}\text { Theoretica } \\
\mathbf{l} \text { value of } \\
\text { shear } \\
\text { capacity } \\
\mathbf{/ k N}\end{array}$ & $\begin{array}{c}\text { Test value } \\
\text { of shear } \\
\text { capacity } \\
/ \mathbf{k N}\end{array}$ & $\begin{array}{c}\text { Relative } \\
\text { error } \\
\mathbf{\%}\end{array}$ \\
\hline $\mathrm{A}$ & 2.5 & 10865.4 & 55.14 & 56 & 1.54 \\
$\mathrm{~B}$ & 2.5 & 9586.2 & 48.65 & 47.83 & -1.71 \\
$\mathrm{C}$ & 2.5 & 12097.6 & 61.40 & 60.25 & -1.91 \\
$\mathrm{D}$ & 2 & 10865.4 & 57.54 & 56.75 & -1.40 \\
$\mathrm{E}$ & 3 & 10865.4 & 52.94 & 54 & 2.00 \\
\hline
\end{tabular}

\section{Conclusions}

A static test of the shear bearing capacity of 12 glulam beams in 6 groups $(10 \mathrm{~T}$-section beams and 2 rectangular beams) was conducted to explore the shear performance of glulam T-section beams and deduce the calculation formula of shear bearing capacity. The failure mechanism, loaddeflection curve, and load-strain relationship of glulam Tsection beams were analyzed. The following conclusions were drawn.

(1) All glulam T-beams have shear failure along grain under concentrated load in mid-span and show evident plastic characteristics during the loading process. Compared with rectangular beams, their ultimate bearing capacity and bending stiffness are increased by $71.36 \%$ and $131.28 \%$, respectively. The shear capacity and bending stiffness of glulam T-beams increase with the increase in the web width and decrease with the increase in the shear span ratio. Changing the web width has a great influence on the ultimate shear capacity of glulam T-beams, and changing the shear span ratio has a great influence on the flexural stiffness of members.

(2) The load-strain curve of the mid-span section of a glulam T-beam in the elastic stage is linearly distributed along the height direction of the web, which conforms to the assumption of the plane section. After entering the plastic stage, the neutral axis of the component gradually moves downward, the timber on the compression side of the component yields when it is destroyed, and the tensile property of the timber on the tension side does not fully play. The failure position is located at the lower side of the theoretical neutral axis.

(3) The shear lag effect of glulam T-beams is obvious. Increasing the web width will enhance the shear lag effect of glulam T-beams, whereas increasing the shear span ratio will weaken the shear lag effect of glulam T-beams.

(4) The formula $\tau_{R}=\frac{1.3 C_{f} \tau_{Q}}{A^{1 / 5}}$ can be used to calculate the shear strength of glulam T-beams, and the formula $V=\frac{0.87}{\lambda^{1 / 5}} \tau_{Q} b h_{0}$ can be used to calculate the shear bearing capacity of glulam T-beams.

In this study, the shear performance of glulam T-beams was studied, and the failure mode and mechanism of glulam T-beams under concentrated load at mid-span were revealed. The effects of web width and shear span ratio on the shear performance of glulam T-beams were explored. The calculation formulas of the shear strength and bearing capacity of glulam T-beams were proposed, which had a certain reference for the subsequent study and engineering application of glulam T-beams. However, each experimental group comprised only three variables due to the limited number of components. In future studies, more variables or other variables can be studied to improve the reliability of conclusions and formulas. In addition, this experiment did not consider the influence of the change in flange parameters on the shear performance of glulam T-beams, which can be explored in subsequent studies.

\section{Acknowledgements}

This work was supported by the International S\&T Cooperation Program of China (Grant no. 2014DFA53120) and Research on Manufacturing Technology of Modern Glulam Structure of China (Grant no. 9010263203077).

This is an Open Access article distributed under the terms of the Creative Commons Attribution License.

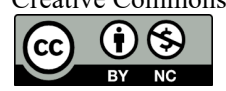

\section{References}

1. He, M. J., He, G. R., Liang, F., Li, Z., "The development of wood structure in China in recent 20 years". Building Structure, 49 (19), 2019, pp.83-90.

2. Lu, W. D., Yang, H. F., Liu, W. Q., Yue, K., Cheng, X. W., "Development, application and Prospect of Glulam structure". Journal of Nanjing Tech University (Natural Science Edition), 33 (05), 2011, pp. 105-110.

3. Keenan, F. J., Kryla, J., Kyokong, B., "Shear strength of spruce glued-laminated timber beams". Canadian Journal of Civil Engineering, 12 (3), 1985, pp. 661-672.

4. Soltis, L. A., Gerhardt, T. D., "Shear design of wood beams: state of the art". In: Forest Products Laboratory, Research Paper: FPL-GTR56, Madison, WI: U.S. Department of Agriculture, Forest Service, 1988, pp. 1-7.
5. Rammer, D. R., Soltis, L. A., "Experimental shear strength of Glulam-laminated beams". In: Forest Products Laboratory, Research Paper: FPL-RP-527, Madison WI, USA: USDA, 1994, pp. 1-38.

6. Lam, F., Craig, B. A., "Shear strength in structural composite lumber". Journal of Materials in Civil Engineering, 12(3), 2000, pp. 196-204.

7. Das, S., "Shear strength of timber beams with end splits". Master thesis of University of Manitoba, Canada, 2012.

8. Kazeroon, R. A., Ahmad, Z., Bkhari, N. M., "The Effect of Span Lengths on the Bending Strength Properties of Glued Laminated Timber Beam". In: CIEC 2015, Singapore: Springer, 2016, pp. 861869.

9. Klapalek, P., Melzerpva, L., "Effect of distribution of Knots on the strength of the glued laminated timber beam". Applied Mechanics and materials, 732, 2015, pp. 365-368. 
10. Glišović, I., Stevanović, B., Petrović, M., "Bending behaviour of glulam beams reinforced with carbon FRP plates". Journal of Civil Engineering \& Management, 21 (7), 2015, pp. 923-932.

11. Gomes Ferreira. J., Cruz, H., Silva, R., "Failure behaviour and repair of delaminated glulam beams". Construction \& Building Materials, 154, 2017, pp. 384-398.

12. Du, H., Hu, X. M., Wang, H. C., Zhang, J., Sun, Z. X., "Shear behavior of oblique screw connectors of Glulam concrete composite beams". Journal of Building Structures, 41 (07), 2020, pp. 191-200.

13. Zhang, J., Wang, W. C., Qiu, R. G., Shen, H., Xu, Q. F., Gao, S., experimental study on short-term flexural behavior of internal prestressed Glulam beams". China Civil Engineering Journal, 52 (05), 2019, pp. 23-34.

14. Zhang, J., Shen, H., Gao, S., Li, W. B., Xu, Q. F., "Study on flexural bearing capacity of prestressed Glulam beams". Journal of Hunan University (Natural Sciences), 45 (05), 2018, pp. 134-142.

15. Zhou, S. R., Feng, S. Y., Xiong, G., Zhu, H., "Experimental research on bending performance of modern glulam beams". Architecture Technolog, 51(03), 2020, pp. 307-310.

16. Feng, J., Wang, X. 1., Xu, Q. G., Wang, X. X., Qin, S. S., "Experimental study on flexural behavior of full-scale laminated Glulam beams". Building structure, 50 (S1), 2020, pp. 252-255.

17. Rao, Z. Y., Wang, J. J., Ning, F., "Experimental Study on Bending Behavior of Glued Wood Inverted T-beam". Journal of Central South University of Forestry \& Technology, 40 (08), 2020, pp. 155-163.

18. Yang, T., Wang, J. J., Ning, F., Rao, Z. Y., "Experimental study on flexural bearing capacity of Glulam T-beams". Journal of Central South University of Forestry \& Technology, 39 (05), 2019, pp. 124131.
19. General Administration of Quality Supervision, Inspection and Quarantine of the People's Republic of China, Standardization Administration of China, GB /T 1931-2009., "Method for determination of moisture content of wood”. Beijing: China Quality Inspection Press, 2009.

20. General Administration of Quality Supervision, Inspection and Quarantine of the People's Republic of China, Standardization Administration of China, GB /T 1937-2009., "Method of testing in shearing strength parallel to grain of wood”. Beijing: China Quality Inspection Press, 2009.

21. Liu, Y. F., "Experimental study and numerical simulation on transverse cracking of Glulam curved beams". Master thesis of Harbin Institute of technology, China, 2011.

22. Wang, J. J., Ning, F., Li, J. Z., Zhu, H. Y., "Experimental Study and Finite Element Simulation Analysis of the Bending Properties of Cross-Laminated Timber (CLT) Two-Way Plates". Journal of Engineering Science and Technology Review, 13(4), 2020, PP. 132142 .

23. Shi, Y., Zhou, X. H., Song, K., Liu, J., "Study on bending stiffness of cold-formed thin-walled steel beam OSB plate composite floor". Journal of Architectural Science and engineering, 32 (5), 2015, pp.50-57.

24. Yuan, J. G., Yu, Z. W., “Basic principles of concrete structure design". Beijing: China Railway Publishing House, China, 2012, pp. 89-93. 